\title{
Landslide types in the Slani Potok gully, Croatia
}

\author{
Petra Jagodnik ${ }^{1}$, Vedran Jagodnik ${ }^{1}$, Željko Arbanas ${ }^{1}$ and Snježana Mihalić Arbanas*,2 \\ ${ }^{1}$ Faculty of Civil Engineering, University of Rijeka, HR-51000 Rijeka, Croatia \\ 2 Faculty of Mining, Geology and Petroleum Engineering, University of Zagreb, HR-10000 Zagreb, Croatia; ( ${ }^{*}$ corresponding author: smihalic@rgn.hr)
}

doi: $10.4154 / g c .2020 .04$

\begin{tabular}{|c|c|}
\hline & Abstract \\
\hline $\begin{array}{l}\text { Article history: } \\
\text { Manuscript received May 21, } 2019 \\
\text { Revised manuscript accepted January 28, } 2020 \\
\text { Available online February 29, } 2020\end{array}$ & $\begin{array}{l}\text { The Slani Potok gully }\left(0.48 \mathrm{~km}^{2}\right) \text { is situated in the central part of the Vinodol Valley }\left(64.57 \mathrm{~km}^{2}\right) \\
\text { in Croatia, and it was formed in the Eocene flysch deposits. So far, the area of Slani Potok has } \\
\text { been mainly referred in the scientific literature as being subjected to unusually intense soil ero- } \\
\text { sion processes (i.e., "excessive erosion"), associated with landslides. However, the landslides } \\
\text { were never investigated in detail, given the available research methods only involved field inves- } \\
\text { tigations. Therefore, the landslide types according to the most commonly used landslide clas- } \\
\text { sifications have remained undetermined. In this paper, landslide types in the Slani Potok gully } \\
\text { are presented, identified and mapped based on the visual interpretation of seven different LiDAR } \\
\text { topographic derivatives computed from the } 1 \text { x } 1 \text { m DTM available from March } 2012 \text {. The geo- } \\
\text { morphological historical landslide inventory of the Slani Potok gully was created, consisting of } \\
181 \text { landslide phenomena. Landslides cover } 69 \% \text { of the area (0.33 km²) of the Slani Potok gul- } \\
\text { ly. The size of the smallest landslide is } 65 \mathrm{~m}^{2} \text {, and of the largest is } 10,563 \text { m². Landslides are } \\
\text { very small to moderate-small, shallow to moderate-shallow, and mainly successive in distribu- } \\
\text { tion. Most of the landslides initiate along the margins of the gully channel walls, and extend to } \\
\text { the gully channel bottom. Such a large number of identified landslides, as well as their specific } \\
\text { spatial arrangement within the gully, indicates that sliding processes predominantly affect the } \\
\text { morphologic development of the Slani Potok gully, and that the soil erosion is the secondary } \\
\text { process in the study area. }\end{array}$ \\
\hline
\end{tabular}

\section{INTRODUCTION}

Landslides play an important role in the evolution of landforms (CROZIER, 2010). They represent a serious hazard in many parts of the world (GUZZETTI et al., 2012), often as an element of multiple-hazard events (SCHUSTER \& KOCKELMAN, 1996). Economic losses caused by landslides can be significant and continuously increasing, especially in developing urbanized areas. Despite the importance of landslides for the local communities and policies, it has been estimated that landslide maps cover less than $1 \%$ of the slopes in the landmasses, and that systematic information on landslide types, their spatial distribution and statistics is lacking (GUZZETTI et al., 2012; MIHALIĆ ARBANAS $\&$ ARBANAS, 2014). The preparation of landslide inventories, which can provide information about the locations of individual landslide phenomena of certain types (GUZZETTI, 2006), represents the preliminary step in landslide susceptibility, hazard and risk assessment (GUZZETTI et al., 2012). Nevertheless, the knowledge of landslide types and understanding their socioeconomic significance for a particular area can facilitate rational decision making with regard to landslide prevention, control and mitigation (SCHUSTER, 1996; CLAGUE \& ROBERTS, 2012).

The Slani Potok gully $\left(0.48 \mathrm{~km}^{2}\right)$ is situated in the central part of the Vinodol Valley $\left(64.57 \mathrm{~km}^{2}\right)$, in the north-western coastal part of the Republic of Croatia. The gully was formed in the Eocene flysch deposits, which are mainly composed of marls, siltstone and sandstone (BLAŠKOVIĆ, 1999). The area of Slani Potok is characterized by unusually intense erosion processes (ALJINOVIĆ et al., 2010), which have been commonly termed "excessive erosion" in the scientific literature (e.g., BENAC et al., 2005; JURAK et al., 2005). Such erosion, associated with sliding processes (BENAC et al., 2005; ALJINOVIĆ et al., 2010), occurs due to the lithological composition of the flysch deposits, the pres- ence of swelling minerals, sodium rich pore water, and the occurrence of the mineral thenardite $\left(\mathrm{Na}_{2} \mathrm{SO}_{4}\right)$ (JURAK et al., 2005), which has been documented as the first discovery of this mineral in Croatia (MILEUSNIĆ et al., 2004). Thenardite was also observed in the Eocene flysch bedrock in the upper part of the Slano Blato landslide (KOŠIR et al., 2013) located in the Vipava Valley in Slovenia, which is characterized by geological conditions similar to the geological conditions in the Vinodol Valley.

Landslides and soil erosion, as well as the engineering geological conditions in the Slani Potok area have been investigated since the middle of the last century. Historical data about landslides can be found in several important engineering geological and geotechnical reports that provide information about materials and geological contacts between the superficial deposits and the bedrock (e.g., DOMJAN, 1965; BIONDIĆ \& VULIĆ, 1970; ŠTAJDUHAR, 1976), or propose a review of suggested remedial measures (e.g., TOMIĆ et al., 1977). DOMJAN (1965) has reported the first detailed data on flysch bedrock and superficial deposits, based on rotary drilling of 15 boreholes in the area of the County Road 5064 passing along the border of the Slani Potok gully in its upper part. BIONDIĆ \& VULIĆ (1970) have created the first Engineering geological map at a scale of 1:5,000 of the Slani Potok and Mala Dubračina area, based on the results of rotary drilling and detailed field investigations. Although this map provides valuable information about superficial deposits in the study area, it doesn't indicate locations and boundaries of individual landslide phenomena, but only depicts the entire areas affected by active and dormant landslides. More recent engineering geological data about landslides activated in the Slani Potok gully and its wider area can be found in ĐOMLIJA et al. (2019b), as well as in several geotechnical design documents for landslide remediation purposes (e.g., ARBANAS, 2000, 2002; GROŠIĆ, 2013). 
Despite the fact that the sliding processes in the Slani Potok gully have been known and studied for more than 50 years, the landslide types according to the most commonly used landslide classifications (e.g., VARNES, 1978; CRUDEN \& VARNES, 1996) have still remained undetermined. This is probably due to the availability of only conventional methods for landslide investigations, i.e., geomorphological field mapping and visual interpretation of stereoscopic aerial photography, the application of which is limited to the production of detailed landslide inventories in morphologically complex and densely forested areas (GUZZETTI et al., 2012), such is the Vinodol Valley (CAEN, 2008).

In the last two decades, analysis of surface morphology from the high resolution (HR) Digital Terrain Models (DTMs) created from LiDAR (Light Detection and Ranging) data (WEHR \& LOHR, 1999; RAZAK et al., 2011; JABOYEDOFF et al., 2012) are effective in landslide inventory mapping (GUZZETTI et al., 2012). One of the leading methods used for the identification and mapping of landslides is the visual interpretation of HR LiDAR topographic derivatives (SCAIONI et al., 2014), which enables the effective mapping of relatively large rotational slides and complex failures (e.g., HAUGERUD et al., 2003; VAN DEN EECKHAUT et al., 2007; KASAI et al., 2009; POPIT, 2017), small and shallow rainfall-induced landslides (e.g., ARDIZZONE et al., 2007; BERNAT GAZIBARA et al., 2019), and debris flows (e.g., HAUGERUD et al., 2003). Landslide mapping is effective in large forested areas (e.g., VAN DEN EECKHAUT et al., 2007; PETSCHKO et al., 2016), smaller cultivated (e.g., ARDIZZONE et al., 2007) and urbanized areas (e.g., MIHALIĆ ARBANAS, et al., 2016; BERNAT GAZIBARA et al., 2019). The visual interpretation is mainly performed using the hillshade map, the slope map, and the contour line map (e.g., HAUGERUD et al., 2003; ARDIZZONE et al., 2007; VAN DEN EECKHAUT et al., 2007; BELL et al., 2010; PETSCHKO et al., 2016), although other LiDAR derivatives (i.e., maps) proved to be effective in landslide mapping, such as the curvature map (e.g., AMUNDSEN et al., 2010), or topographic roughness map (e.g., POPIT \& VERBOVŠEK, 2013; POPIT et al., 2016; BERNAT GAZIBARA et al., 2019).

The Vinodol Valley was a pilot area of the Croatian-Japanese scientific project Risk Identification and Land-Use Planning for Disaster Mitigation of Landslides and Floods in Croatia conducted from 2009 to 2014 (MIHALIĆ \& ARBANAS, 2013). For the whole valley area, airborne laser scanning (ALS) was perfomed in March 2012 using the multi-return LiDAR system and the DTM at 1 x $1 \mathrm{~m}$ resolution was created, which opened up the opportunities for systematic and detailed scientific investigations of geomorphological processes in this area.

The first landslide inventory map for the area of the Dubračina River Basin in the Vinodol Valley, which also includes the Slani Potok gully, was created by TOŠEVSKI (2013) based on field geomorphological mapping coupled with the visual interpretation of HR LiDAR DTM. For this purpose, three types of topographic datasets (i.e., the hillshade map, the slope map and the contour line map with 1 metre contour interval) are derived from the DTM. A total of 39 landslide phenomena were identified in the Dubračina River Basin, including 20 landslides located in the Slani Potok gully. A total of 16 landslides are visually identified on LiDAR derivatives. Despite the fact that a recent and new landslide mapping technique (GUZZETTI et al., 2012) was applied in this study, and that for each delineated landslide the dimensions and geometry are determined, the types of landslide processes occurring in the Dubračina River Basin have not been specifically determined. Landslides in TOŠEVSKI (2013) are classified only based on their size, according to the classification of landslides proposed by ŠESTANOVIĆ (2001).

This paper presents landslide types in the Slani Potok gully, which are identified and mapped based on the detailed visual interpretation of seven different LiDAR derivatives available from March 2012. Landslides are classified according to the newest classification of landslide types proposed by HUNGR et al. (2014), who modified and updated the Varnes landslide classification system (Varnes, 1978), mainly in relation to the definition of landslide-forming materials. The significance of this study is the geomorphological historical landslide inventory of the Slani Potok gully that shows the individual boundaries and spatial arrangement of 181 past and current landslides, classified according to recent advances in the understanding of landslide phenomena, as well as the relevant materials and mechanisms (HUNGR et al., 2014). These new findings related to landslide types and their spatial arrangement can certainly contribute to the local sustainable development, as well as to a better understanding of the morphological evolution of the Slani Potok gully.

\section{STUDY AREA}

The Slani Potok gully is located in the Vinodol Valley $\left(64.57 \mathrm{~km}^{2}\right)$, which is situated in the north-western coastal part of the Republic of Croatia (Fig. 1a). The gully is located in the central part of the Vinodol Valley, i.e., in the Dubračina River Basin (Fig. 1b), and covers an area of $0.48 \mathrm{~km}^{2}$ (ĐOMLIJA, 2018). The gully was formed within the populated rural area, and it is surrounded by several settlements and roads (Fig. 1c and d). The County Road CR 5064 passes along the border of the gully channel in its upper part, in which the badlands are formed (Fig. 1d), and this road has often been damaged due to the influence of active geomorphological processes. County road CR 5089, which passes along the Dubračina riverbed in the middle part of the Valley (Fig. 1c), is connected with the county road CR 5064 by several local roads passing through the settlements situated along the lateral margins of the Slani Potok gully channel.

Delineation of the Slani Potok gully is performed during the preparation of the historical erosion inventory of the Vinodol Valley (ĐOMLIJA, 2018), which depicts past and current soil erosion phenomena identified and mapped based on the detail visual interpretation of eight types of HR LiDAR $1 \times 1 \mathrm{~m}$ topographic derivatives. The methodology, as well as the LiDAR derivatives used for identification and mapping of soil erosion processes in the Vinodol Valley, which was also applied to delineation of the Slani Potok gully, is presented in detail in ĐOMLIJA et al. (2019a).

The Slani Potok gully is the largest gully phenomenon formed in the Vinodol Valley (ĐOMLIJA, 2018). According to the classification of gullies based on gully dimensions (FREVERT, 1955), and the relative age and stage of gully growth (KOSTENKO, 1975), the Slani Potok gully can be classified as a large and relatively old gully, characterized by great length, marked branching of the gully channel and a detrital cone located at the gully mouth. The classification of gully types for the area of the Vinodol Valley is proposed by ĐOMLIJA (2018), based on the degree of development of the gully drainage network determined according to STRAHLER $(1952,1957)$, and the morphological characteristics of the gully channel. According to these criteria, the Slani Potok is a complex gully (ĐOMLIJA, 2018), with a branched gully channel the shape of which is mostly de- 


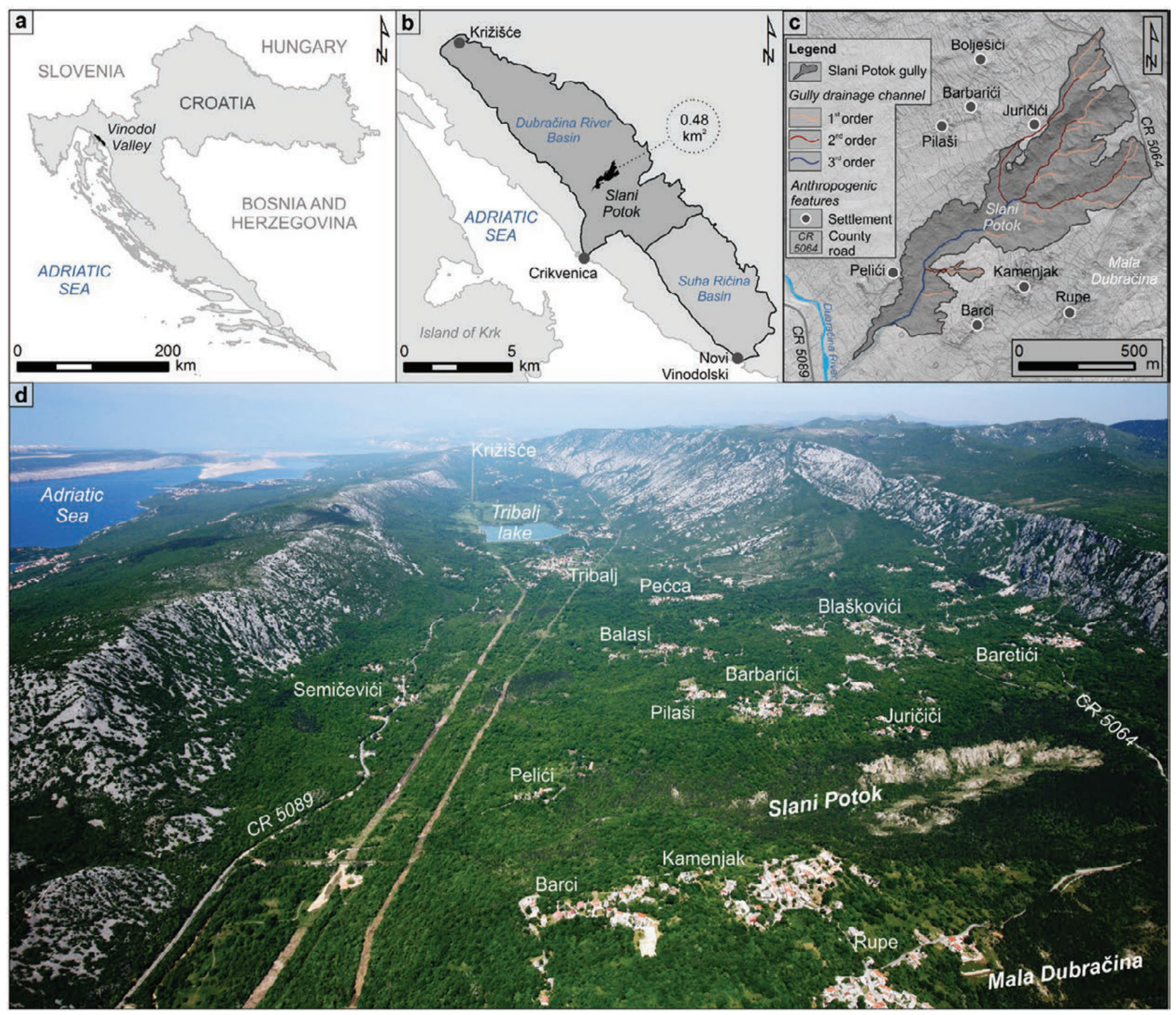

Figure 1. Geographical location of the Vinodol Valley (a); geographical location of the Slani Potok gully within the Vinodol Valley, with the spatial coverage of the Dubračina River Basin and the Suha Ričina Basin (b); geomorphology of the Slani Potok gully on the hillshade map derived from LiDAR DTM, with elements of drainage network determined according to STRAHLER $(1952,1957)$ (c); and the aerial photograph of the Dubračina River Basin, photographed from the southeast to the northeast (d).

fined by the third-order stream network of the main gully channel that has been extended by the second-order and first-order drainage channels (Fig. 1c). Numerous landslides activated within the Slani Potok gully have significantly contributed to its morphological evolution.

The main part of the gully area is covered by forest vegetation, as are most of the surrounding slopes (Fig. 1d). The forests cover an area of $32.19 \mathrm{~km}^{2}$ in the Vinodol Valley (CAEN, 2008). The climate is maritime (ZANINOVIĆ et al., 2008), with mean annual precipitation between 300 and $700 \mathrm{~mm}$. The rainy season lasts from November to May, with precipitation at its maximum in November when rainstorms of high erosive potential frequently occur.

The steep flanks of the Vinodol Valley (Fig. 1d) are composed of Upper Cretaceous and Palaeogene carbonate rocks (ŠUŠNJAR et al., 1970; BLAŠKOVIĆ, 1999), while the lower parts and the bottom of the Valley are built of a Palaeogene flysch rock mass, mainly composed of marls, siltstones and sandstones in alteration. However, the flysch bedrock is mostly covered by various types of superficial deposits formed by geomorphological processes active both in the carbonate and flysch rock mass (BERNAT et al., 2014; ĐOMLIJA et al., 2014). A detail from the engineering geological map 1:25,000 (ĐOMLIJA, 2018), which was created based on the visual interpretation of HR LiDAR imagery, is shown in Figure 2. Older and recent talus deposits have been accumulated at the foot of the limestone cliffs, as a result of different types of mass movements, predominantly of rock falls, rock topples, and irregular rock slides (ĐOMLIJA, 2018). Large, individual limestone boulders have been transported to the hypsometrically lower parts of the cliff foothills, probably as a result of larger rock falls and debris avalanches. Breccias have an irregular, patchy occurrence and they are characterized by the different sizes and shapes of the sedimentary bodies. Flysch bedrock in the central part of the Vinodol Valley is mostly covered by the hillwash and older talus deposits, mainly composed of clays ranging from high plasticity clays to gravely clays (PAJALIĆ et al., 2017), mixed in different ratios with the rock fragments from limestone and flysch. Due to gravitational transport and mixing 


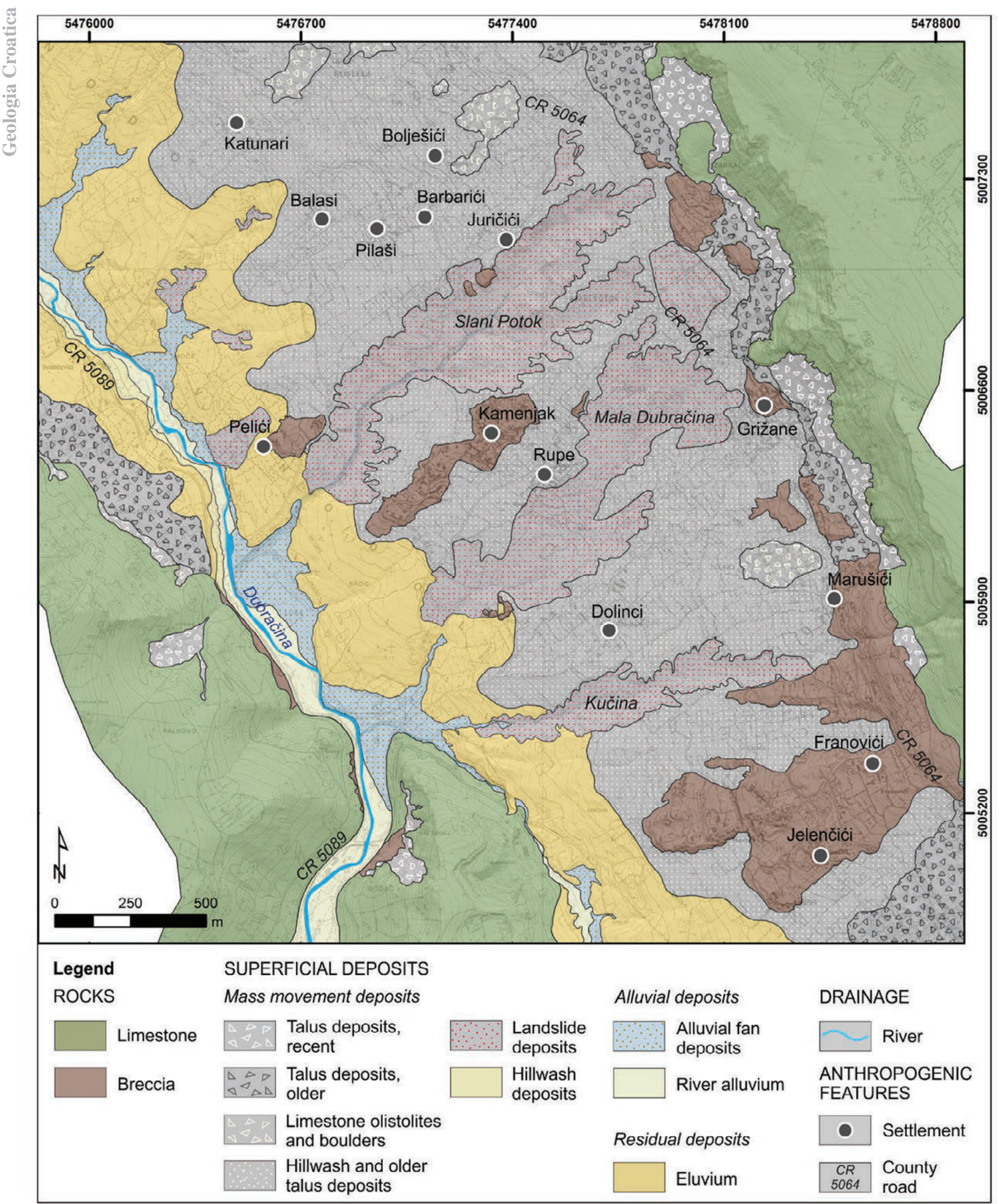

Figure 2. A detail from the engineering geological map of the central part of the Vinodol Valley 1:25,000 (ĐOMLIJA, 2018).

of fragments, these soils can significantly vary in thickness, from less than one to several metres, and as well as in their physicomechanical properties across the study area (ĐOMLIJA, 2018).

Flysch slopes have been dissected by several relatively large and deep gullies, such as the Slani Potok $\left(0.48 \mathrm{~km}^{2}\right)$, Mala
Dubračina $\left(0.31 \mathrm{~km}^{2}\right)$ and Kučina $\left(0.15 \mathrm{~km}^{2}\right)$ (Fig. 2). Within these gullies, the landslide deposits have been formed as a result of sliding processes. Landslide deposits represent zones of acculumation of numerous landslides identified and mapped withing the gullies (ĐOMLIJA, 2018), composed of weathered flysch bed- 
rock, which represents a material lying at the contact between the soil and rock (PAJALIĆ et al., 2017). Due to the sliding processes, flysch bedrock can sporadically crop out in the steep upper parts of the gully channel walls. The soil erosion processes have also been active within the gullies; so alluvial fan deposits are situated at the mouth of the gully channels, and they form the almost continuous sheet at the foot of the northwestern flysch slopes. Eluvium mostly covers the bedrock in the hypsometrically lower parts of the flysch slopes. The hillwash deposits have been formed in places at the foot of the flysch slopes, by the recurring sheet erosion processes on the surface of the eluvium. Alluvial fans and hillwash deposits partially cover the river alluvium deposites, located around the Dubračina riverbed.

\section{MATERIALS AND METHODS}

\subsection{High resolution LiDAR data}

The LiDAR data used in this study were acquired in March 2012 by airborne laser scanning using the multi-return LiDAR system. The last returns (i.e., bare-ground returns) were acquired at the point density of 4.03 points per square metre, with an average point distance of 0.498 meters. These data were used for the creation of the DTM with a 1 x $1 \mathrm{~m}$ resolution, using a Triangulated Irregular Network interpolation (MITAS \& MITASOVA, 1999). The average accuracy of the altitude data is $30 \mathrm{~cm}$, but it may be lower in areas covered with dense vegetation.

Seven types of topographic datasets are derived from DTM using the standard tools in the ArcGIS 10.0 software, and they are used for the topographic analysis of the Slani Potok gully: (i) the hillshade map; (ii) the slope map; (iii) the contour line map; (iv) the topographic roughness map; (v) the profile curvature map; (vi) the planform curvature map, and (vii) the stream power index map.

Hillshade maps were created using the sun azimuth angles of $315^{\circ}$ and $45^{\circ}$, and the sun elevation angles of $45^{\circ}$ and $30^{\circ}$. The hillshade map with the sun azimuth angle of $315^{\circ}$ and the sun elevation angle of $45^{\circ}$ (i.e., hillshade map $315^{\circ} / 45^{\circ}$ ) was used in the analysis in general, but in order to obtain the optimal shaded relief for each part of the studied area (e.g., VAN DEN EECKHAUT et al., 2005) hillshade maps were overlapped in two combinations: (a) the semi-transparent (50\%) hillshade map $45^{\circ} / 45^{\circ}$ over the hillshade map $315^{\circ} / 45^{\circ}$, and (b) the semi-transparent (50\%) hillshade map $45^{\circ} / 30^{\circ}$ over the hillshade map $315^{\circ} / 45^{\circ}$.

The slope map was reclassified into seven slope angle classes, according to IGU (1968). The contour line map was created with $1-m$ contour intervals. The topographic roughness map was calculated according to the Slope Variability Method (e.g., POPIT \& VERBOVŠEK, 2013), where the slope variability implies a difference between the minimum and the maximum slope angle in the selected area. The input parameter for creation of the topographic roughness map was the slope map. First, the maximum slope angle raster $\left(S_{\max }\right)$ and the minimum slope angle raster $\left(S_{\min }\right)$ were generated, and the topographic roughness map, i.e., slope variability $(S V)$ was then calculated as:

$$
S V=S_{\max }-S_{\min }
$$

The input parameters for the creation of the stream power index map were the slope map and the flow accumulation map. The stream power index map was calculated according to MOORE et al. (1991) as:

$$
S P I=\ln (\text { flow accumulation }) \times\left(\frac{\text { slope }}{100}\right)
$$

\subsection{Delineation of landslides based on visual interpretation of HR LiDAR topographic derivatives}

Discernible topographic characteristics remaining at the surface after a landslide occurrence, i.e., topographic signatures (RIB \& LIANG, 1978; ANTONINI et al., 2002; GUZZETTI, 2006) depend on the landslide type (CRUDEN \& VARNES, 1996), whereby the same type and rate of a mass movement results in a similar topographic signature (GUZZETTI et al., 2012). Moreover, landslides do not occur randomly in an area (GUZZETTI et al., 2002), but are instead the results of the interplay of physical processes and mechanical laws which control the landslide size, shape and spatial evolution (CROZIER, 1986; CRUDEN \& VARNES, 1996). The main features that have enabled recognition of topographic signatures specific for certain landslide features (VARNES, 1978) in this study are: (a) shape; (b) morphometric characteristics; (c) texture; and (d) appearance. These recognition features are visually analysed on different LiDAR derivatives, as shown by the example of landslide identification and mapping in Figure 3.

Landslides were first searched on the hillshade map (Fig. 3a), because the hillshade map most clearly reflects the pseudo threedimensional effect of a surface (GUZZETTI et al., 2012). However, the topography of landslide features for a particular number of landslide phenomena in the study area is not clearly expressed on the hillshade map, as in the example shown in Figure 3a. A semilunar crown (pointed with red arrows in Fig. 3) can be, in most cases, easily recognized on the slope map (Fig. 3b), the topographic roughness map (Fig. 3c), and the profile curvature map (Fig. 3d). Although contours generally most clearly reflect the shape of the landslide crown (e.g., AMUNDSEN et al., 2010; PETSCHKO et al., 2016), this is not the case in the presented example (Fig. 3b). Abrupt changes in slope morphology, e.g., steep slope angles coupled with the slope concavity, are specific to the main scarp (pointed with blue arrows), and these morphometric characteristics can be easily recognized on the slope map (Fig. 3b) for almost all landslides in the Slani Potok gully. For a particular number of landslides in this study, these recognition features could have been easily observed on the profile curvature map too. For most of the landslides, the flanks (pointed with black arrows) are best reflected by the rough texture (Fig. 3c), convex slope morphology (Fig. 3d), and partially by the contour lines (Fig. 3b). The shape of a zone of accumulation (pointed with purple arrows) is mainly well expressed on the contour line map (Fig. 3b). However, the planform curvature map (Fig. 3e) and the stream power index map (Fig. 3f) were particularly useful for the recognition and precise delineation of a zone of accumulation. A hummocky appearance, rough texture and frequent changes of curvature, which are specific for the landslide foot (pointed with cyan arrows), can be recognized on the slope map (Fig. 3b), the topographic roughness map, and the profile curvature map (Fig. 3d) for almost all the inspected landslides. The planform curvature map (Fig. 3e), and the stream power index map (Fig. 3f) also reflect the landslide toe (pointed with green arrows), while the slope map (Fig. 3b), the topographic roughness map (Fig. 3c), and the profile curvature map reflect the landslide tip (pointed with white and gray arrows), mainly in the cases of well preserved topography.

Landslides are mapped with polygons (Fig. 3g) by one and the same expert according to established mapping criteria, which imply that certain recognition features are visually analysed on the most effective LiDAR derivatives (Fig. 3). The recognition of landslide phenomena was performed by screening the LiDAR de- 


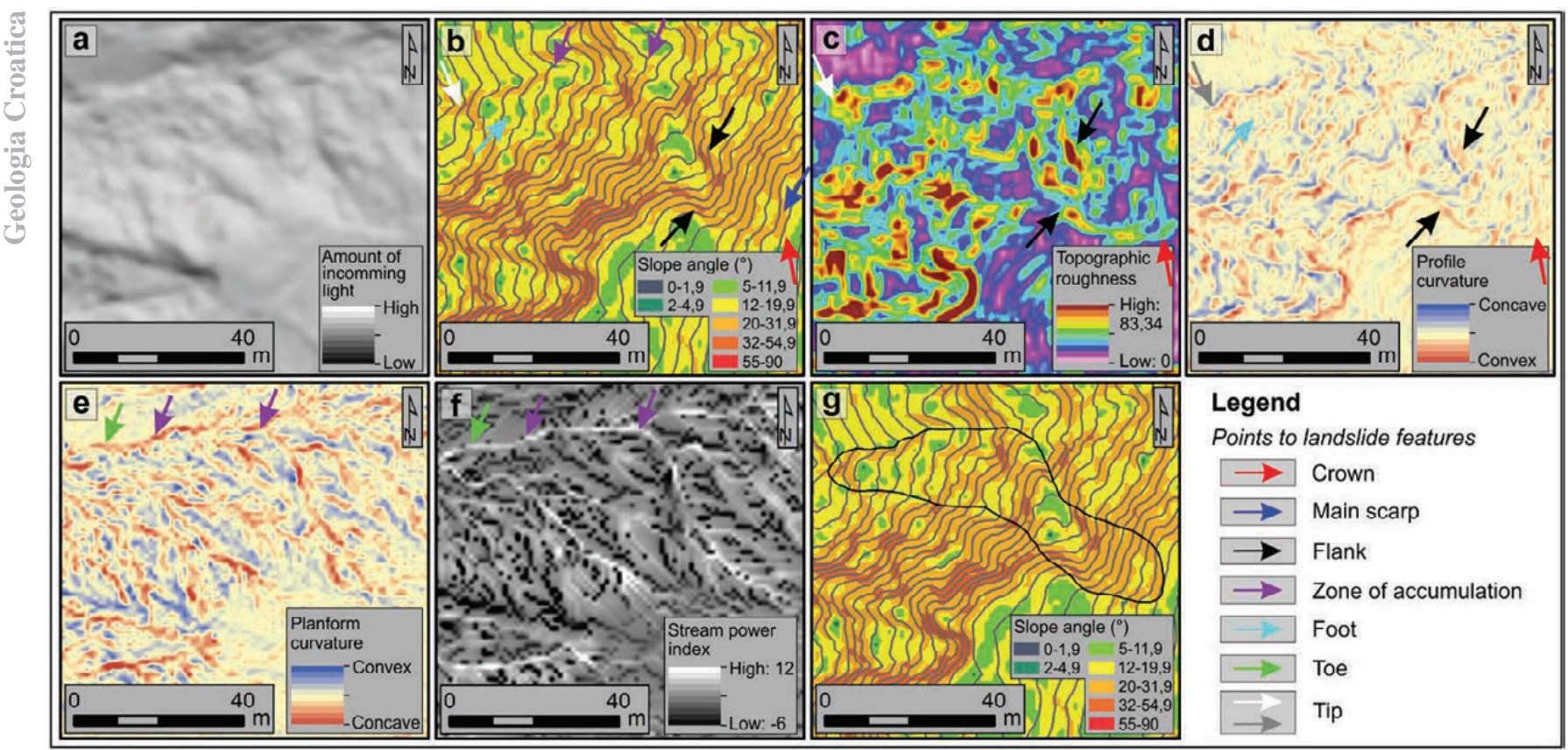

Figure 3. An example of landslide features topography visible on HR LiDAR topographic derivatives: (a) the semi-transparent ( $50 \%$ ) hillshade map $45^{\circ} / 45^{\circ}$ over the hillshade map $315^{\circ} / 45^{\circ}$; (b) the contour line map of 1 metre contour interval over the slope map; (c) the topographic roughness map; (d) the profile curvature map; (e) the planform curvature map; and (f) the stream power index map; $(\mathrm{g})$ delineated polygon representing landslide presented on the contour line map over the slope map.

rivatives on a scale between $1: 1,000$ and 1:5,000, relative to the size of the Slani Potok gully. However, the precise delineation of landslides was performed on considerably larger scales, mainly ranging between 1:100 and 1:300. The portions of individual landslide features are separately drawn on different LiDAR maps, depending on their visibility on each analysed LiDAR map. These separately drawn lines of landslide feature boundaries are subsequently merged into a unique polygon representing the landslide.

\subsection{Identification of landslide types}

Landslides are classified according to the updated Varnes classification of landslide types (VARNES, 1978) proposed by HUNGR et al. (2014). The main objective of this recent classification system of landslide types is to modify the definitions of landslideforming materials, to provide compatibility with the accepted geotechnical and geological terminology of rocks and soils. The type of movement for each landslide is determined based on the shape of the delineated polygon, while the landslide depth is estimated based on the polygon size (CRUDEN \& VARNES; 1996; SOETERS \& VAN WESTEN, 1996). The type of material is determined based on the reconnaissance geological mapping and from the engineering geological map of the Vinodol Valley $1: 25,000$ (ĐOMLIJA, 2018), as well as the general knowledge of geological (DOMJAN, 1965; BIONDIĆ \& VULIĆ, 1970; ŠUŠNJAR et al., 1970; BLAŠKOVIĆ, 1999) and geotechnical conditions (ARBANAS, 2000, 2002; PAJALIĆ et al., 2017; ĐOMLIJA et al., 2019b) in the study area. Each polygon is assigned with the landslide identifier number, consisting of letters indicating the landslide type, and numbers indicating the ordinal number in order of landslide delineation.

Landslide dimensions are calculated using the standard tools in ArcGIS 10.0. The areas were automatically calculated, and the total lengths were manually measured. Descriptive statistics for each landslide type (HUNGR et al., 2014) are calculated based only on the total number of completely identified landslides, i.e., landslides where the delineated polygons depict the entire land- slide body. This approach in the statistical analysis was applied in order to obtain the realistic data set for determination of landslide dimensions characteristic for the Slani Potok gully. Namely, the areas and lengths of delineated polygons of landslides with certain reactivated elements are smaller than they would be if the same landslides had not been reactivated. Therefore, such polygons are excluded from the descriptive statistic analysis.

The relative landslide age and the state of activity were not determined in this study. The main reason for this is the fact that the determination of these attributes is based on the overall appearance of the landslide topography on analysed imagery (MCCALPIN, 1984; WIECZOREK, 1984; KEATON \& DEGRAFF, 1996). In the case of the Slani Potok area, this is difficult to perform correctly because of the soil erosion processes active within the gully (e.g., JURAK et al., 2005), which can significantly modify the landslide topography even in the case of recent landslide phenomena (e.g., MALAMUD et al., 2004; BELL et al., 2012).

\subsection{Field verification}

Identification of landslides on LiDAR derivatives is partially verified by multiple field recognitions, which were mostly conducted during the winter and early spring of 2015 and 2016, in the vegetation leaf-off period. Portions of individual landslides are identified in the field, where it was possible to recognize mainly the landslide crowns and main scarps, as well as to determine the landslide-forming materials. Generally, field identification of landslide phenomena and their types identified on LiDAR maps is considerably limited for two main reasons, and thus the number of landslides that are also identified in the field is not expressed in this study.

Firstly, the study area is a large and branching gully (Fig. 1c) characterized by relatively steep gully walls that are mostly covered by dense forest (Fig. 1d). Therefore, only certain smaller gully portions in its upper denuded part (Fig. 1d) can be accessed, from which the researcher can obtain a distant view of the landslides 
that is desirable for effective field recognition (GUZZETTI et al., 2012). From such spatially restricted positions, it is not easy for a researcher to quantify the landslide phenomena observed in the opposite gully channel wall, located at a considerable distance away. Moreover, in the Slani Potok gully, a researcher can generally distinguish landslides only in their upper parts, while individual zones of accumulation, the characteristics of which are crucial for determination of the type of movement (SOETERS \& VAN WESTEN, 1996), are difficult to distinguish in the field.

Secondly, landslides in the Slani Potok gully are identified and mapped based on the remote sensing data collected in 2012, after which a certain number of landslide phenomena occurred in the study area. There are also erosion processes active in the Slani Potok gully, particularly in its denuded portion, where they continuously modify the landslide topography. Therefore, it is not possible to straightforwardly validate the landslide inventory map prepared using the available LiDAR derivatives, given that a certain number of landslides in the Slani Potok gully are partially or totally modified by later landslides or erosion processes.

However, the Slani Potok gully is a relatively small study area when considering the main assumptions for the preparation of a landslide inventory (GUZZETTI et al., 2012), and it represents a single geomorphological unit of uniform geological and morphological conditions. For such small study areas, the principle of uniformitarianism (VARNES \& IAEG, 1984) can be fully applied (GUZZETTI et al., 2012), unlike for larger study areas characterized by marked variations in the local slope conditions, where the necessity for field verification of the remote sensing results increases, and where it is commonly performed on $15 \%$ of the area covered by a landslide inventory (GALLI et al., 2008).

\section{RESULTS}

Based on the visual interpretation of HR LiDAR topographic derivatives, two types of landslides (HUNGR et al., 2014) are identified in the Slani Potok gully: (a) debris slide; and (b) debris slidedebris flow.

\subsection{Debris slide (DS)}

A debris slide (DS) represents the sliding of a veneer of colluvium or residual soil over a harder substrate on a shallow planar surface parallel to the ground (HUNGR et al., 2014). Such translational sliding (CRUDEN \& VARNES, 1996) generally results in an elongated shape of a landslide phenomenon (SOETERS \& VAN WESTEN, 1966). According to HUNGR et al. (2014), debris represents the unsorted and texturally mixed soil material originating from the weathering of bedrock which, if it is finegrained, is generally of low plasticity. Specifically, the larger part of the Slani Potok gully is covered by the veneer of residual and colluvial deposits formed from the flysch bedrock, which are determined as debris material according to their origin, textural characteristics and geotechnical properties (e.g., DOMJAN, 1965; BIONDIĆ \& VULIĆ, 1970; ĐOMLIJA et al., 2019b).

Debris slide phenomena in the Slani Potok gully are tipically activated along the contact between the flysch bedrock and superficial deposits, as well as along the contact of the residual and colluvial deposits. Debris slides have been initiated both along the margins of the gully channel walls (Fig. 4a to c), and within the inner parts of the gully channel (Fig. 4d-f). Certain landslide phenomena cause direct damage to local roads, as shown in Fig. 4c; the local road in the Kamenjak settlement affected by a landslide in February 2014.

Examples of debris slides representative of the study area on certain LiDAR maps used in the visual analysis are presented in Fig. 5. There are significant differences in the visibility of landslide features on the hillshade map in all the presented examples. The topography of debris slides DS 32 (Fig. 5a), DS 40 (Fig. 5b) and DS 6 (Fig. 5c) is clearly visible on the hillshade map. In contrast, the topography of debris slides DS 28 (Fig. 5a), DS 36, DS 37, DS 38 (Fig. 5b), DS 2 and DS 4 (Fig. 5c) is not so clear on the hillshade map, while all debris slides shown in Figure 5e are almost unrecognizable on the hillshade map. The topography of the largest debris slide DS 2 identified in the study area $\left(A=10,536 \mathrm{~m}^{2}\right.$; $L=150 \mathrm{~m}$ ), shown in Fig. 5 c, is relatively smooth, and it has been

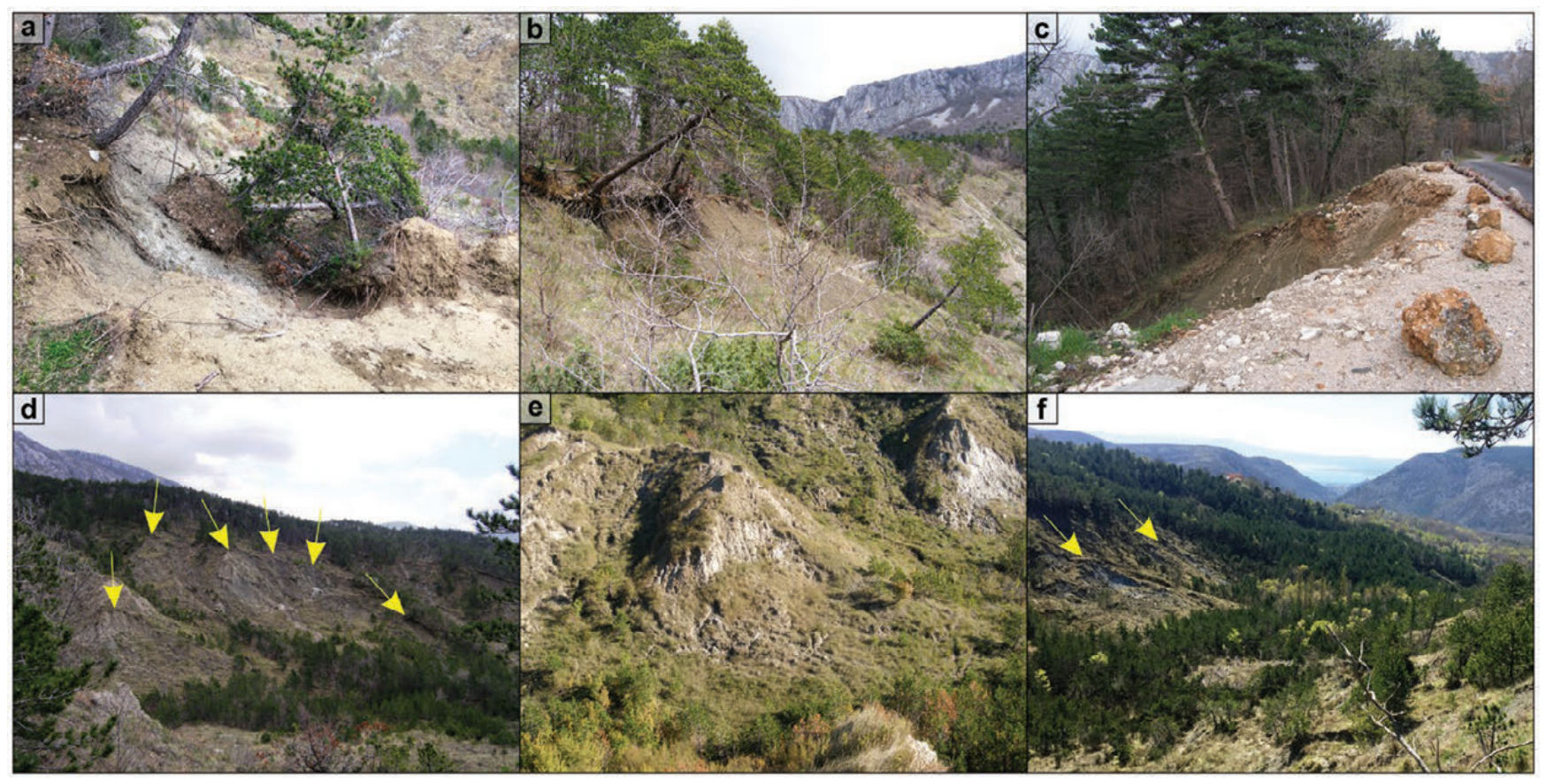

Figure 4. Photographs of debris slide phenomena identified in the Slani Potok gully: (a-c) debris slides activated along the edges of the gully channel walls, where the landslide shown in (c) was activated on the local road in the Kamenjak settlement; (d-f) debris slides activated within the inner parts of the gully channel. Arrows in (d) and ( $\mathrm{f}$ ) point to the crowns of debris slides. 

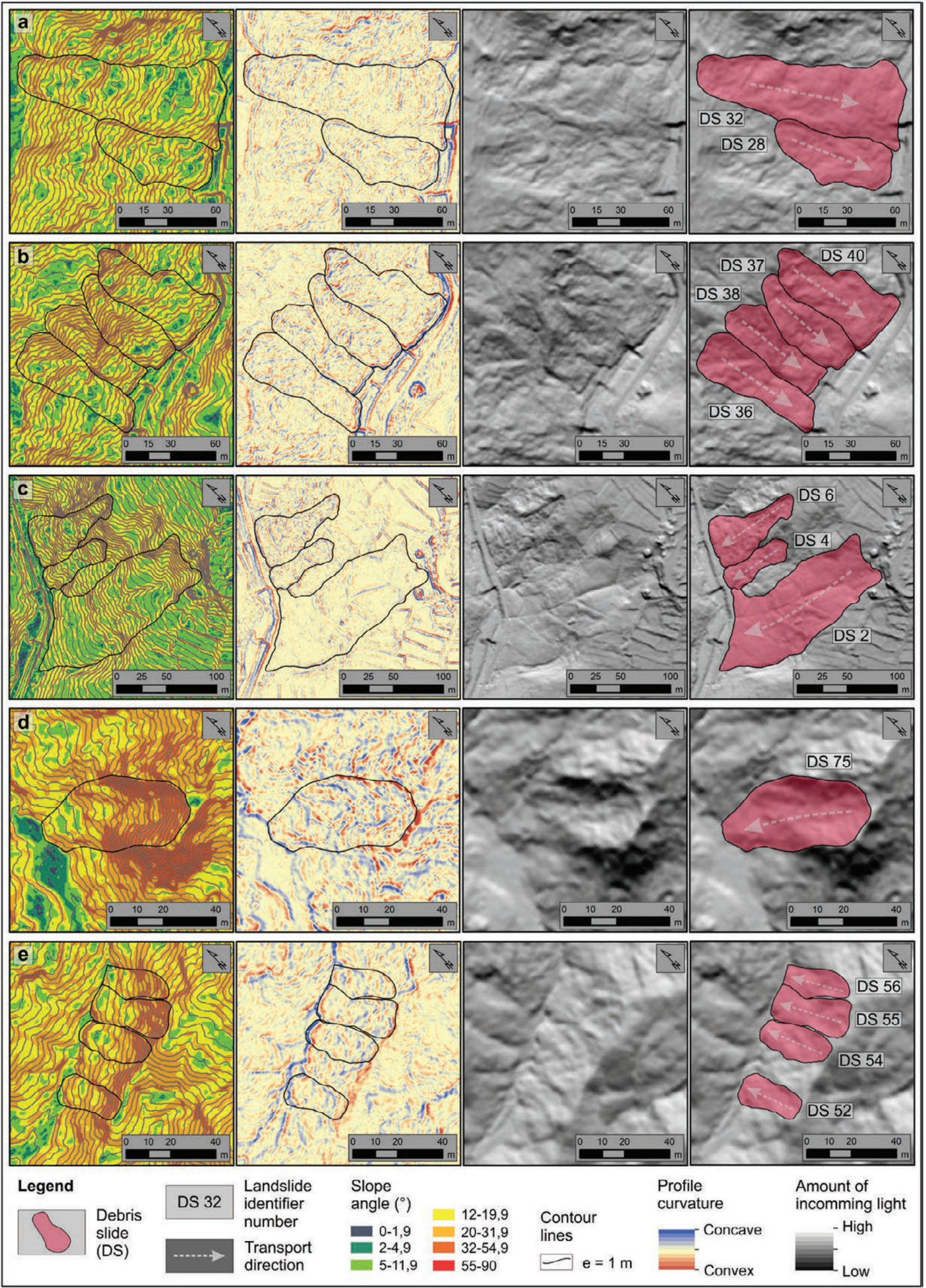

Figure 5. Examples of debris slide (DS) topography in the Slani Potok gully presented on (from left to right) the contour line map of 1-m contour interval over the slope map, the profile curvature map, and the semi-transparent (50\%) hillshade map $45^{\circ} / 45^{\circ}$ over the hillshade map $315^{\circ} / 45^{\circ}$ without, and with delineated landslide polygons: (a) DS 32 and DS 28; (b) DS 36, DS 37, DS 38 and DS 40; (c) DS 2, DS 4 and DS 6; (d) DS 75; and (e) DS 52, DS 54 , DS 55 and DS 56. 
Table 1. Descriptive statistics for debris slides (DS) identified in the Slani Potok gully, calculated according to the number of completely identified landslides.

\begin{tabular}{|c|c|c|c|c|c|c|c|c|}
\hline $\begin{array}{l}\text { No. of complete } \\
\text { landslides }\end{array}$ & $\begin{array}{l}\text { Total area } \\
\qquad\left(\mathrm{m}^{2}\right)\end{array}$ & $\begin{array}{l}\text { Landslide } \\
\text { dimension }\end{array}$ & Avg & Min & $\begin{array}{c}25^{\text {th }} \\
\text { percentile }\left(Q_{1}\right)\end{array}$ & $\begin{array}{c}50^{\text {th }} \\
\text { percentile }\left(Q_{2}\right)\end{array}$ & $\begin{array}{c}7^{\text {th }} \\
\text { percentile }\left(Q_{3}\right)\end{array}$ & Max \\
\hline \multirow{2}{*}{99} & \multirow{2}{*}{178,746} & Area, $A\left(\mathrm{~m}^{2}\right)$ & 1,806 & 65 & 536 & 1,240 & 2,355 & 10,536 \\
\hline & & Total length, $L(\mathrm{~m})$ & 66 & 12 & 37 & 61 & 85 & 174 \\
\hline
\end{tabular}

modified by artificial drainage channels. However, the slope map clearly reflects the topographic features of almost all debris slides, especially the crowns, main scarps, and zones of depletion. On the slope map, as well as on the profile curvature map, even the smallest debris slides (e.g., Fig. 5d and e) can be easily recognized. Debris slides predominantly have an elongated shape, such as those shown in Fig. 5b and 5e. However, certain phenomena are characterized by widening of the landslide accumulation, such as the debris slides DS 32 (Fig. 5a) and DS 6 (Fig. 5c).

There are 107 debris slide phenomena identified in the study area. Their total area is $196,134 \mathrm{~m}^{2}$. Of the total number of debris slide phenomena, 99 debris slide polygons represent completely identified landslides, which are used as a representative data set for the descriptive statistic analysis (Tab. 1). The smallest debris slide has an area of $65 \mathrm{~m}^{2}$, and the largest has an area of $10,536 \mathrm{~m}^{2}$. However, $75 \%$ of all the identified debris slides have an area $<2,355 \mathrm{~m}^{2}$. The maximum total length of debris slide phenomena is $174 \mathrm{~m}$, with an average value of $66 \mathrm{~m}$. According to the classification of landslides based on volume and depth proposed by ICL (2018), debris slides identified in the Slani Potok gully represent very small to moderate-small, shallow to moderateshallow landslides, with estimated volumes in a range between $<10^{3}$ and $10^{5} \mathrm{~m}^{3}$ and estimated depths in a range between one and five metres.

\subsection{Debris slide-debris flow (DSDF)}

A debris slide-debris flow (DSDF) generally initiates as a shallow planar sliding, and the movement transforms into a flow after moving a relatively short distance (HUNGR et al., 2014). For a particular number of landslide phenomena in the Slani Potok gully, a relatively shallow planar sliding of debris material provides the source for a flow type of movement of limited extent. Thus, the landslides are characterized by an elongated shape, given that displacement may extend over a considerable distance (SOETERS \& VAN WESTEN, 1996). Flow features can generally be clearly recognized in the zone of accumulation of landslides, by the hummocky appearance of their lobate convex forms. An example of debris slide-debris flow phenomenon identified in the Slani Potok gully is presented in Figure. 6.

Two types of debris slide-debris flow can be distinguished in the Slani Potok gully: (a) the A-type debris slide-debris flow, in which the displaced material flows to the gully thalweg and accumulates at the bottom of the gully channel (Fig. 7a); and (b) the B-type debris slide-debris flow, in which the flow of the displaced material continues along the gully thalweg and infills the bottom of the gully channel (Fig. 7b).

Examples of representative topography of an A-type debris slide-debris flow (DSDFa) on certain LiDAR maps are presented

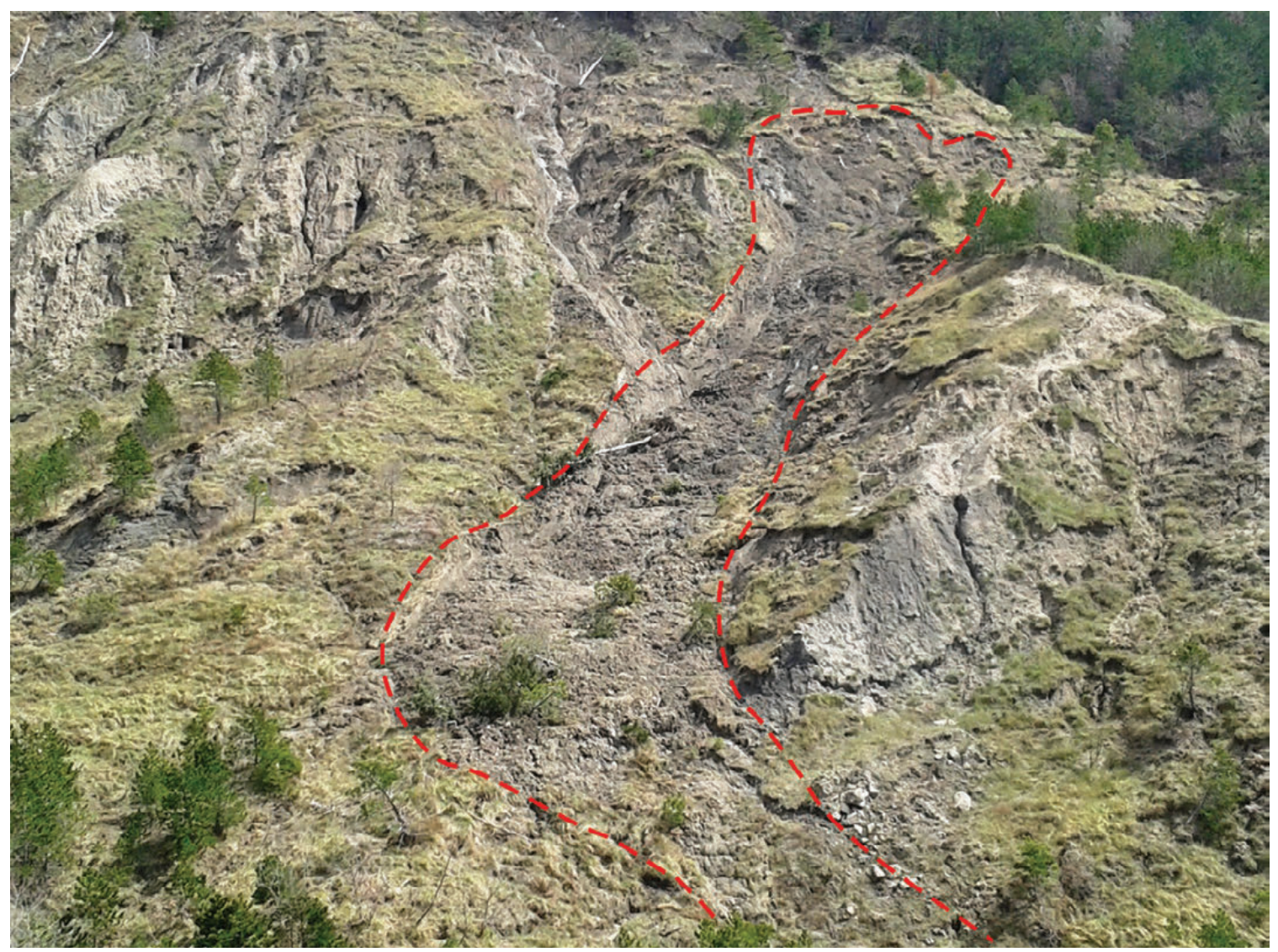

Figure 6. An example of debris slide-debris flow phenomenon identified in the Slani Potok gully. 

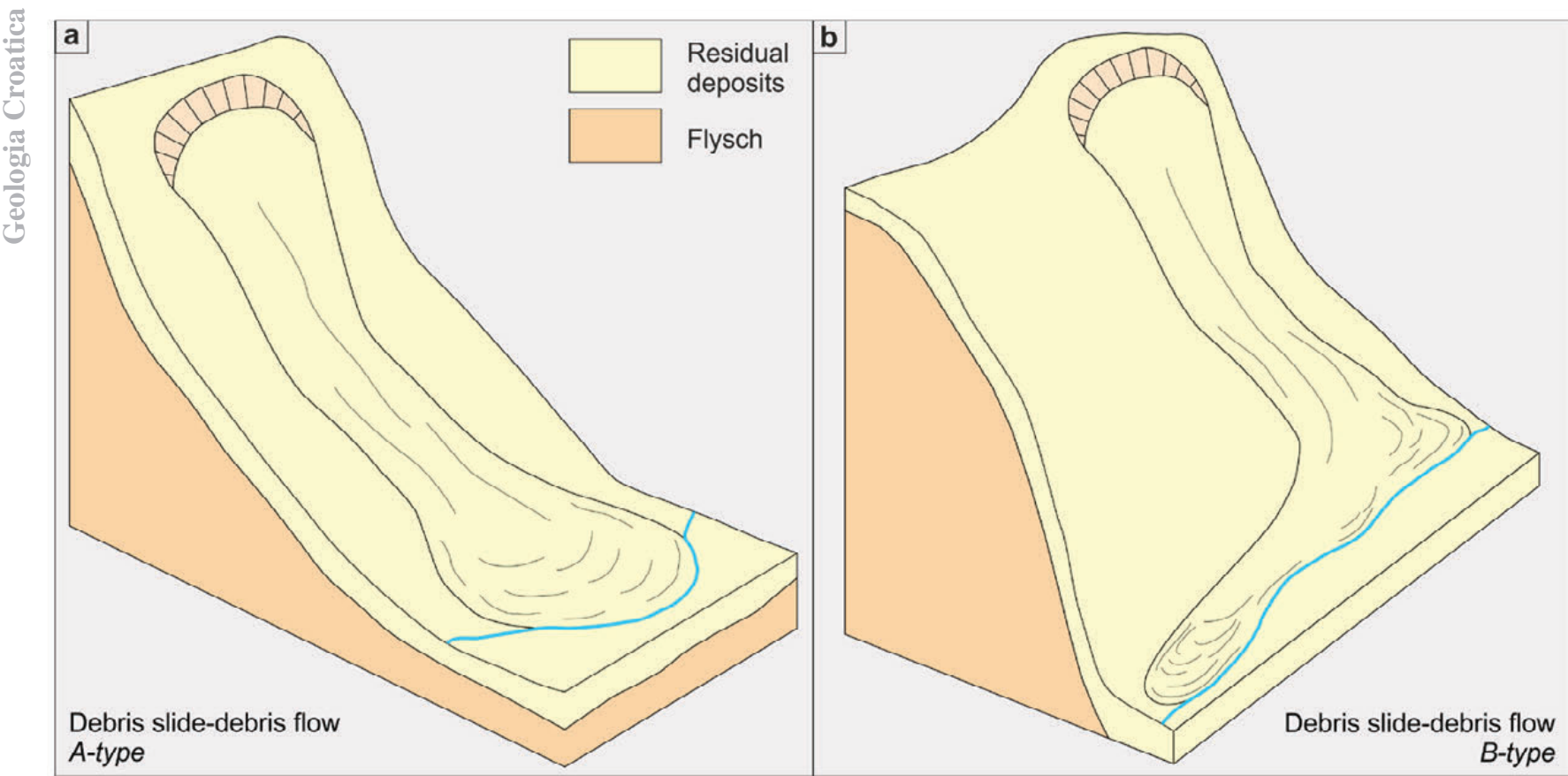

Figure 7. Simplified models representing the types of debris slide-debris flows identified in the Slani Potok gully: (a) the A-type debris slide-debris flow; (b) the B-type debris slide-debris flow.

in Figure. 8. The phenomenon DSDFa 1 (Fig. 8a) is characterized by the smoothed appearance on the hillshade map and the profile curvature map. However, almost all landslide features are clearly expressed on the slope map and the contour line map. The landslide has an elongated shape, with a total length of $136 \mathrm{~m}$, and is generally narrow. The narrowing of the landslide body is more pronounced in the transition between the zone of depletion and the zone of accumulation. The morphological characteristics of the flow movement, e.g., the hummocky relief and lobate convex forms in the landslide foot (SOETERS \& VAN WESTEN, 1996)
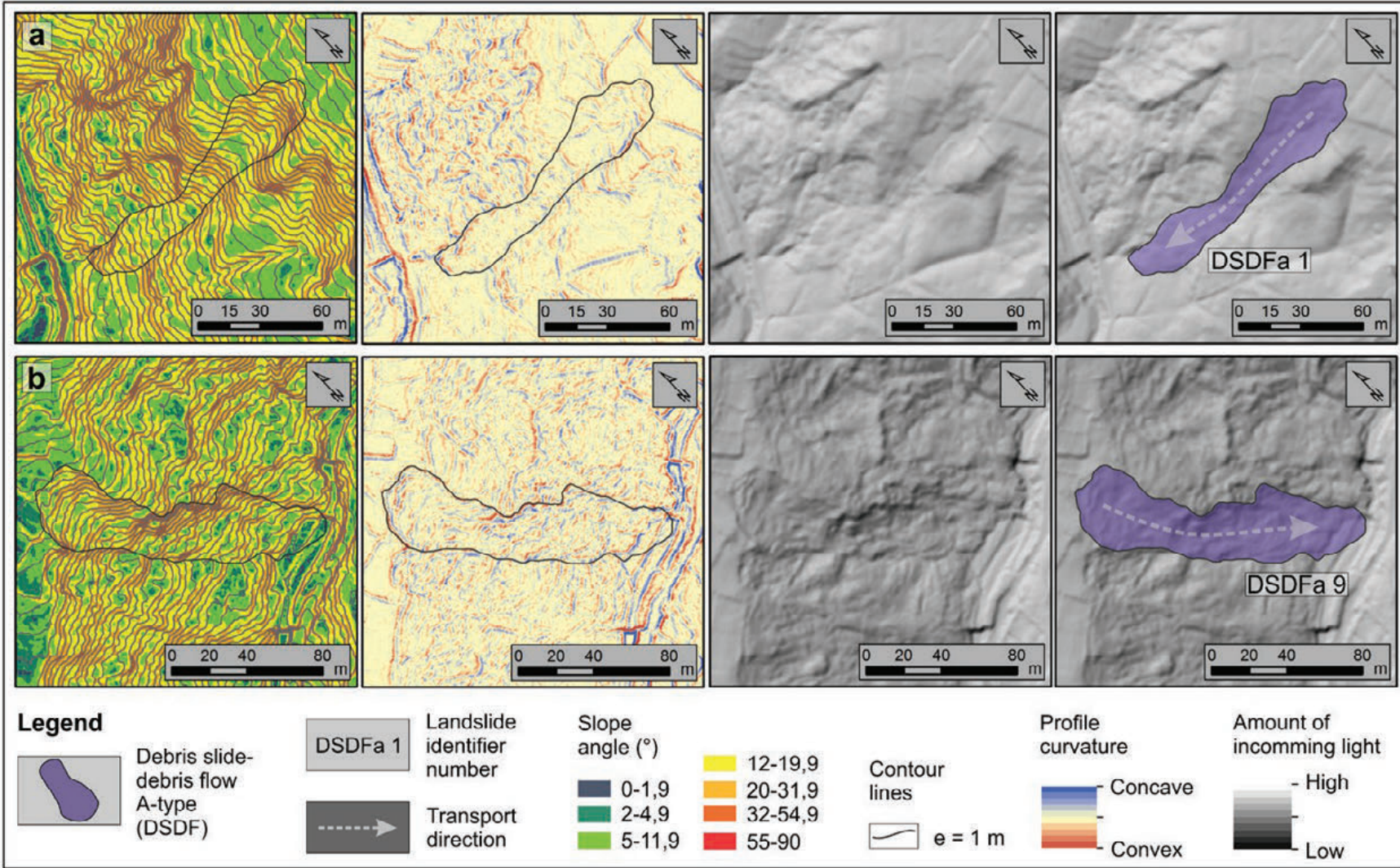

Figure 8. Examples of an A-type debris slide-debris flow (DSDFa) topography in the Slani Potok gully presented on (from left to right) the contour line map of 1-m contour interval over the slope map, the profile curvature map, and the semi-transparent (50 \%) hillshade map $45^{\circ} / 45^{\circ}$ over the hillshade map $315^{\circ} / 45^{\circ}$ without, and with delineated landslide polygons: (a) DSDFa 1; and (b) DSDFa 9. 


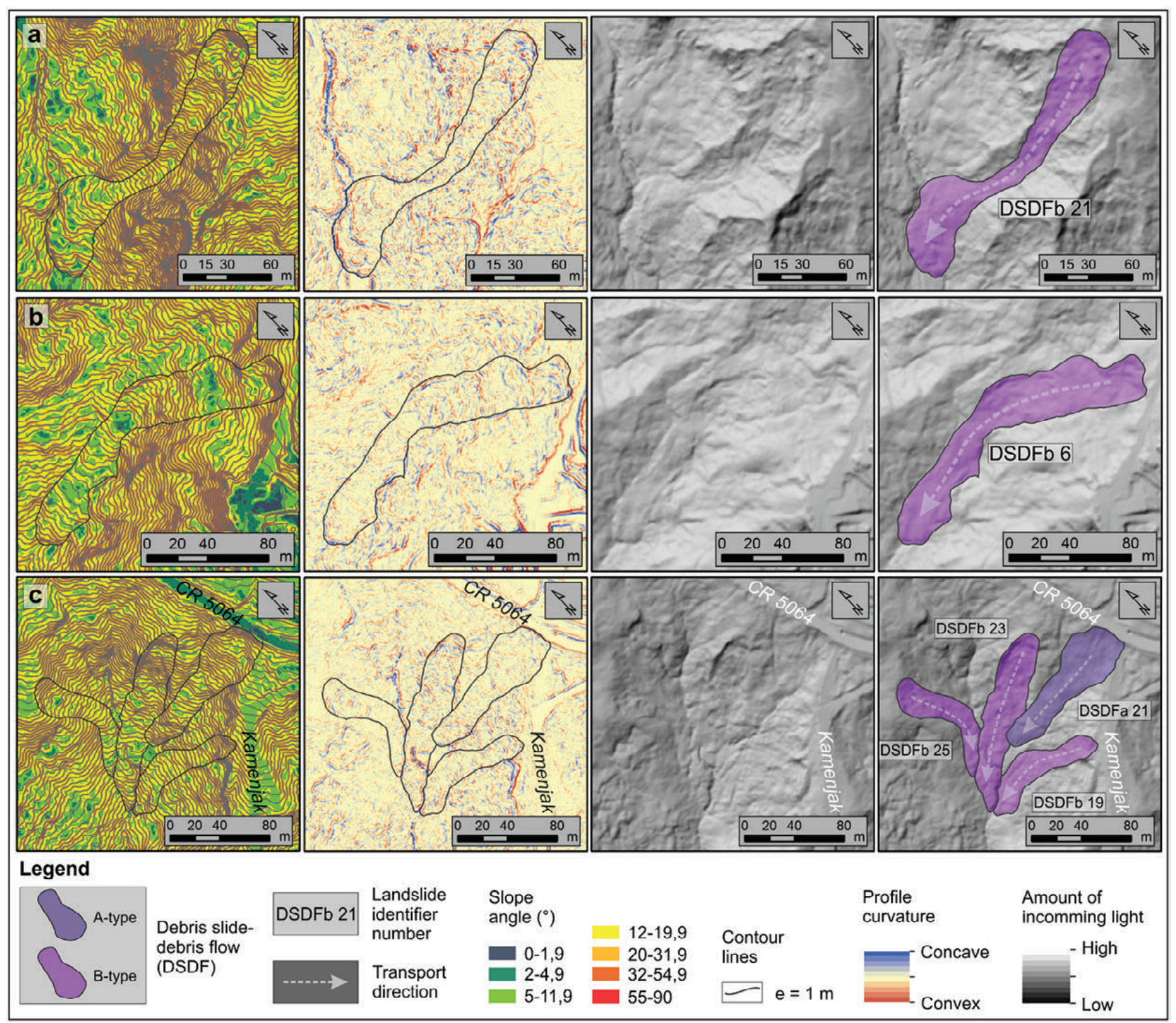

Figure 9. Examples of a B-type debris slide-debris flow (DSDFb) topography in the Slani Potok gully presented on (from left to right) the contour line map of 1-m contour interval over the slope map, the profile curvature map, and the semi-transparent (50\%) hillshade map $45^{\circ} / 45^{\circ}$ over the hillshade map $315^{\circ} / 45^{\circ}$ without, and with delineated landslide polygons: (a) DSDFb 21; (b) DSDFb 6; and (c) DSDFb 19, DSDFb 23 and DSDFb 25 . In (c), the landslide polygon of DSDFa 21 is also presented.

are better expressed in the case of debris slide-debris flow DSDFa 9 (Fig. 8b), the topography of which is almost entirely clearly recognizable on all LiDAR derived maps. This phenomenon also has an elongated shape, with a total length of $157 \mathrm{~m}$. The direction of transport, and thus the slightly curved shape of the landslide accumulation, was predetermined by the presence of the adjacent landslide phenomenon DS 32.

An example of a B-type debris slide-debris flow (DSDFb) with well preserved topography of all the landslide features is presented in Figure 9a. The phenomenon DSDFb $21\left(A=5,262 \mathrm{~m}^{2}\right.$; $L=212 \mathrm{~m}$ ) can easily be recognized on the hillshade map, especially by the lobate convex accumulation infilling the bottom of the gully channel. Such lobate forms, coupled with the transverse ridges, can be the most easily recognized on the profile curvature map and the contour line map. An elongated and mainly curved shape also characterizes the landslide phenomena shown in Fig. $9 \mathrm{~b}$ and 9c. The topography of the DSDFb $6\left(A=5,541 \mathrm{~m}^{2}\right.$; $L=209 \mathrm{~m}$ ) is generally smooth and thus poorly visible on the hillshade map. However, the main scarp and the right flank can be clearly recognized on the slope map, while the zone of accumulation can be recognized on the contour line map and the profile curvature map. In contrast, the topography of certain smaller landslides located between the county road CD 5064 and the local road toward the Kamenjak settlement (Fig. 9c) is almost entirely unrecognizable on the hillshade map. Only the rough texture is visible on the hillshade map, as well as the main scarp of the landslide phenomenon DSDFb 23, which is partially covered by the foot of the phenomenon DSDFa 21. However, in the cases of all shown phenomena, accumulations are well expressed on the slope map and the profile curvature map. Landslide sizes and shapes are predetermined by the existence of the drainage channels formed within the gully head, i.e., the paths of the displaced mass follow the gully thalwegs and thus they partially cover each other.

There are 74 debris slide-debris flows identified in the Slani Potok gully. Their total area is 145,226 $\mathrm{m}^{2}$. In total, 39 landslides are identified as an A-type debris slide-debris flow (total area of $70,466 \mathrm{~m}^{2}$ ), and 35 landslides are identified as a B-type debris 
Table 2. Descriptive statistics for debris slide-debris flows (DSDF) identified in the Slani Potok gully, calculated according to the number of completely identified landslides.

\begin{tabular}{|c|c|c|c|c|c|c|c|c|c|}
\hline $\begin{array}{c}\text { Debris } \\
\text { flow-debris slide }\end{array}$ & $\begin{array}{l}\text { No. of complete } \\
\text { landslides }\end{array}$ & Total area $\left(\mathrm{m}^{2}\right)$ & $\begin{array}{l}\text { Landslide } \\
\text { dimension }\end{array}$ & Avg & Min & $\begin{array}{c}25^{\text {th }} \\
\text { percentile }\left(Q_{1}\right)\end{array}$ & $\begin{array}{c}50^{\text {th }} \\
\text { percentile }\left(Q_{2}\right)\end{array}$ & $\begin{array}{c}75^{\text {th }} \\
\text { percentile }\left(Q_{3}\right)\end{array}$ & Max \\
\hline \multirow[b]{2}{*}{ A-type } & \multirow[b]{2}{*}{36} & \multirow[b]{2}{*}{67,582} & Area $\left(m^{2}\right)$ & 1,877 & 154 & 843 & 1,728 & 2,535 & 5,659 \\
\hline & & & $\begin{array}{c}\text { Total } \\
\text { length }(\mathrm{m})\end{array}$ & 90 & 22 & 63 & 90 & 113 & 183 \\
\hline \multirow[b]{2}{*}{ B-type } & \multirow[b]{2}{*}{29} & \multirow[b]{2}{*}{69,649} & Area $\left(m^{2}\right)$ & 2,402 & 438 & 937 & 1,809 & 2,738 & 9,734 \\
\hline & & & $\begin{array}{c}\text { Total } \\
\text { length }(\mathrm{m})\end{array}$ & 115 & 41 & 77 & 106 & 143 & 236 \\
\hline
\end{tabular}

slide-debris flow (total area of 74,760 $\mathrm{m}^{2}$ ). In total, 65 delineated debris slide-debris flows are defined as completely identified landslides, and they are thus used as a representative data set for descriptive statistic analysis (Tab. 2). In the Slani Potok gully, the smallest debris slide-debris flow has an area of $154 \mathrm{~m}^{2}$, and the largest debris slide-debris flow has an area of $9,734 \mathrm{~m}^{2}$. An average area of an A-type debris slide-debris flow is $1,877 \mathrm{~m}^{2}$, and 2,402 $\mathrm{m}^{2}$ for a B-type debris slide-debris flow. The average total length of an A-type debris slide-debris flow is $90 \mathrm{~m}$, and $115 \mathrm{~m}$ for a B-type debris slide-debris flow. According to the classification of landslides based on volume and depth proposed by ICL (2018), debris slide-debris flows in the Slani Potok gully represent very small to moderate-small, shallow to moderate-shallow landslides, with estimated volumes in a range between $<10^{3}$ and $10^{5} \mathrm{~m}^{3}$ and estimated depths in a range between one and five metres.

\subsection{Landslide inventory of the Slani Potok gully}

The landslide inventory of the Slani Potok gully consists of 181 dormant and active debris slide and debris slide-debris flow phenomena. According to the classification of landslide inventories (GUZZETTI et al., 2012), it is the geomorphological historical inventory type. The total mapped landslide area is $0.34 \mathrm{~km}^{2}$. One of the largest mapped debris slides $\left(A=10,160 \mathrm{~m}^{2}\right)$ covers part of the area which is outside the Slani Potok gully (see Fig. 11), so the total landslide area within the gully is slightly smaller: $0.33 \mathrm{~km}^{2}$. Landslides cover $69 \%$ area of the Slani Potok gully. The size of the most abundant debris slide in the landslide inventory is approx. 2,500 $\mathrm{m}^{2}$ (Fig. 10a), and the size of the most abundant debris slide-debris flow is approx. 2,700 $\mathrm{m}^{2}$ (Fig. 10b).

Landslides have mostly been activated along the margins of the gully channel walls (Fig. 11). They are characterized by their similar, predominantly elongated shapes. For most of the landslides, the total length is approximately the same as the length of the gully channel walls, except for a certain number of debris slide-debris flows. Debris slides have a more regular spatial arrangement along the gully channel, while most of the debris slidedebris flows are located within the upper and middle parts of the Slani Potok gully. Landslides have a predominantly successive distribution (WP/WLI, 1993). Certain debris slides have been reactivated within the zone of accumulation, and rarely within the zone of depletion. Some landslides are partially to significantly covered with accumulations of adjacent landslides, particularly if they are located near the debris slide-debris flow phenomena.

\section{DISCUSSION}

Debris slides are the most abundant landslide type identified in the Slani Potok gully (107 phenomena of in total 181 mapped landslides), including the smallest $\left(A_{\min }=65 \mathrm{~m}^{2}\right)$, and the largest slides $\left(A_{\max }=10,563 \mathrm{~m}^{2}\right)$. The average size of the debris slide phenomena $\left(A_{\text {avg }}=1,806 \mathrm{~m}^{2}\right)$ is approximately the same as the average size of the A-type debris slide-debris flows $\left(A_{\text {avg }}=1,877 \mathrm{~m}^{2}\right)$. The $75^{\text {th }}$ percentile of the landslide area is also similar for debris slides $\left(A_{Q 3}=2,355 \mathrm{~m}^{2}\right)$ and the A-type debris slide-debris flows $\left(\mathrm{A}_{Q 3}=2,535 \mathrm{~m}^{2}\right)$. The B-type debris slide-debris flows generally represent the largest landslides within the Slani Potok gully $\left(A_{Q 3}=2,738 \mathrm{~m}^{2}\right)$, although the largest mapped phenomenon $\left(A_{\max }=9,734 \mathrm{~m}^{2}\right)$ is smaller than the largest mapped debris slide $\left(A_{\max }=10,563 \mathrm{~m}^{2}\right)$. The B-type debris slide-debris flows also have the maximum total length $\left(L_{\text {avg }}=115 \mathrm{~m}\right.$ ), that is on average almost two times larger than the total length of debris slides $\left(L_{\text {avg }}=66 \mathrm{~m}\right.$ ). The similar elongated shapes (Fig. 11), as well as the similar dimensions of most identified landslides (Tab. 2, 3), are predetermined by the gully shape and dimensions, given the fact that landslides are mostly activated along the margin of the gully channel walls and transported to its bottom. Statistics indicate that the relatively large landslide phenomena, with a size
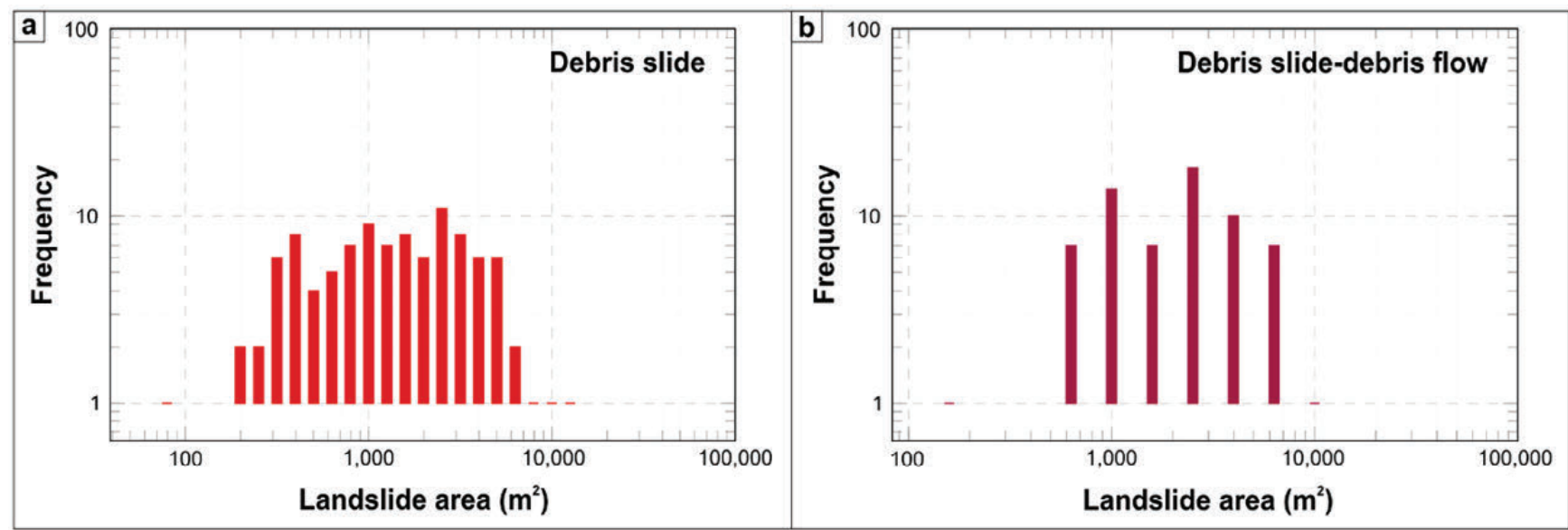

Figure 10. Frequency-size distribution of: (a) debris slide phenomena; and (b) debris slide-debris flow phenomena identified in the Slani Potok gully. 


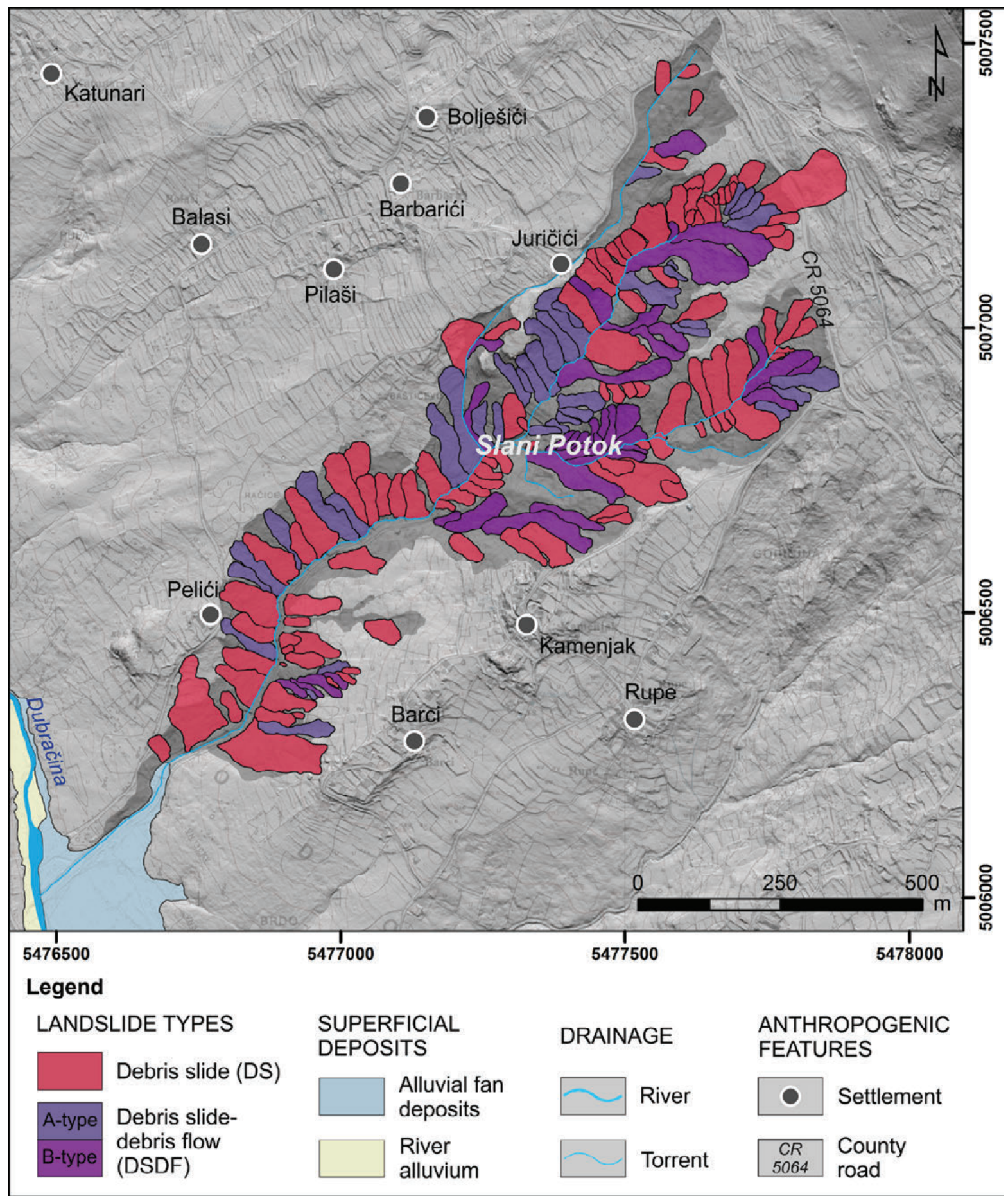

Figure 11. Landslide inventory map of the Slani Potok gully presented on the semi-transparent (80\%) Croatian Base Map 1:5,000 over the hillshade map derived from the LiDAR DTM.

greater than approx. $7,000 \mathrm{~m}^{2}$, are actually rare in the study area (Fig. 10). Relatively small landslide phenomena, particularly debris slides, with sizes less than approx. $300 \mathrm{~m}^{2}$, mainly represent the reactivated parts of older and larger landslides.

There are significant differences in the visibility of landslide topography in the Slani Potok gully on LiDAR derivatives, especially on the hillshade map. In particular, a certain number of landslides are poorly visible (e.g., landslides shown in Figs. 5b, $5 \mathrm{c}$ and $9 \mathrm{c}$ ) to almost unrecognizable (e.g., landslides shown in Fig. 5e) on the hillshade map. This is important to point out, considering that the hillshade map is commonly used as the first map (e.g., VAN DEN EECKHAUT et al., 2007; ARDIZZONE et al.,
2007; PETSCHKO et al., 2016) or even as the only map (e.g., BELL et al., 2012) within landslide studies based on the visual interpretion of HR LiDAR imagery. Namely, if other LiDAR maps had not been simultaneously analysed in this study when visually searching for landslides, a certain number of landslide phenomena in the Slani Potok gully could have easily been omitted, given their poor visibility on the hillshade map.

It must be emphasized, based on the experience in mapping landslides in this study, that using as many LiDAR maps as possible, both singularly and in combinations, to recognize and precisely delineate the boundaries of individual landslide features is important. Specifically, certain LiDAR maps (e.g., the slope map, 
the profile curvature map, and the topographic roughness map) proved to be more useful for the delineation of landslide crowns, but not particularly useful in delineating the landslide accumulations. In the cases of many landslides identified in this study, the effectiveness of the contour line map in recognizing the crowns and flanks (e.g., Fig. 3) has been reduced, although this map is generally considered as highly effective for recognition of these landslide features (e.g., VAN DEN EECKHAUT et al., 2007; AMUNDSEN et al., 2010; PETSCHKO et al., 2016). The planform curvature map and the stream power index map, frequently coupled with the contour line map, were highly effective in the recognition and precise delineation of landslide accumulations and toes in this study.

Among all landslide features, the crowns and toes were the easiest to be delineated, because these features mainly coincide with certain elements of the Slani Potok gully. Namely, most of the landslide crowns coincide with the upper margin of the gully channel (e.g., Fig. 5a to c), which can easily be recognized on the slope map due to the well-defined changes of slope angle between the gully channel and the surrounding slopes. Furthermore, the landslide toes mainly concide with the gully thalweg (Fig. 10), which is almost entirely visible on the planform curvature map, and the stream power index map. In contrast, the flanks and accumulations were the most difficult to delineate precisely, considering that landslides are partially being eroded and that they are mostly successive and thus covered by accumulations of adjacent landslides (Fig. 10). Still, most adjacent landslide accumulations could be recognized and delineated precisely by the linear patterns of the small drainage channels that usually form along their boundary, and which are reflected on the planform curvature map and the stream power index map.

Previous studies on landslide identification and mapping (e.g., ARDIZZONE et al., 2007; VAN DEN EECKHAUT et al., 2007; PETSCHKO et al., 2016) determined that the visual interpretation of LiDAR imagery is characterized by a certain degree of subjectivity, and that it also implies certain simplifications within geomorphological deduction (GUZZETTI et al., 2012). However, the degree of subjectivity in this study is considered to be low, for the following reasons: (i) the topography of landslide phenomena is recognized on a considerable number of different LiDAR derivatives and their combinations according to established mapping criteria (Fig. 3); (ii) landslide types (HUNGR et al., 2014) are distinguished according to the type of movement that is clearly reflected by the shape and size of delineated polygons (SOETERS \& VAN WESTEN, 1996), and they are also verified by field identification (Fig. 4 and 6); (iii) landslides occur within a specific and isolated topographic environment characterized by relatively uniform morphological and geological conditions (e.g., BIONDIĆ \& VULIĆ, 1970; BLAŠKOVIĆ, 1999), that resulted in the limited number of landslide types formed in the same material; and (iv) the landslide inventory of the Slani Potok gully is produced by experts with adequate understanding both of the study area (ĐOMLIJA, 2018) and the associated landslide types (e.g., ARBANAS, 2000, 2002), which significantly contributes to the quality of the results (VAN DEN EECKHAUT et al., 2005). The described mapping procedure has achieved the high geographical accuracy of results in accordance to the $1 \times 1 \mathrm{~m}$ spatial resolution of the LiDAR DTM, and thus the high quality of the landslide inventory. However, landslide mapping was an iterative and time-consuming process, to which the topographic location of landslides within an area with significant soil erosion processes that influence the overall surface topography area also contributed.
The landslide inventory of the Slani Potok gully can be considered as an incomplete inventory (MALAMUD et al., 2004) because the smallest and the largest landslides are missing in the frequency-size distribution (Fig. 10), which is a common characteristic of most historical inventories (e.g., GUZZETTI et al., 2012). Nevertheless, the landslide inventory of the Slani Potok gully provides useful information on the landslide types and realistic boundaries of individual phenomena, as well as their spatial arrangement and relative density within the gully, as well as their average size. These findings can certainly contribute to a more accurate forecast of the propagation and development of future landslide phenomena in the Slani Potok gully, i.e., the landslide types and their proxy dimensions and positions. Although the state of activity is not determined in this study, most of the identified landslides are considered active (WP/WLI, 1993), especially in the upper denuded part of the gully channel. Certain landslide phenomena (e.g., Fig. 4a-c and f) have been activated within the past few years, after airborne laser scanning was performed in March 2012. Therefore, landslide activity, interrelated with soil erosion processes (ĐOMLIJA, 2018), contributes to sediment production within the Slani Potok gully and also might lead to the widening of the gully channel in the future, which can potentially further endanger its surroundings.

\section{CONCLUSIONS}

Two types of landslides according to the updated Varnes classification of landslide types (HUNGR et al., 2014) were identified in the Slani Potok gully situated in the central part of the Vinodol Valley, based on the detailed visual interpretation of seven HR LiDAR 1 x $1 \mathrm{~m}$ topographic derivatives. These are debris slide, and debris slide-debris flow. A geomorphological historical landslide inventory map of the Slani Potok gully (area of $0.48 \mathrm{~km}^{2}$ ) was prepared, comprising a total of 181 landslide phenomena. Landslides cover $69 \%\left(0.33 \mathrm{~km}^{2}\right)$ of the area of the Slani Potok gully. The size of the smallest landslide is $65 \mathrm{~m}^{2}$, and of the largest is $10,563 \mathrm{~m}^{2}$. The size of the most abundant debris slide is approximately $2,500 \mathrm{~m}^{2}$, and the size of the most abundant debris slide-debris flow is approximately $2,700 \mathrm{~m}^{2}$. Landslides mainly exhibit a successive distribution. They generally initiate along the margins of the gully channel walls, and extend to the gully channel bottom. Such a specific spatial arrangement of landslides identified in the Slani Potok gully confirms that the landslide types, geometry, style and distribution of activity are predominantly determined by the topographic location of the landslides, and that those landslides, at the same time, determine the shape and morphological evolution of the gully.

The results of this study indicate that the visual interpretation of HR LiDAR derivatives is an effective method for identification and mapping of landslides in the Slani Potok gully, despite their specific spatial arrangement and relatively small dimensions, and the soil erosion processes influencing the landslide topography. However, in such areas of research, where there are significant differences in the visibility of landslide topography on LiDAR maps, the use of as many LiDAR maps as possible is recommended, to correctly recognize and map boundaries of individual landslide features. This method has also proven to be effective for the classification of landslide types according to the updated Varnes classification (HUNGR et al., 2014), in combination with field investigations that are needed for the determination of landslide-forming material.

The existence of such a large number of landslides identified in the Slani Potok gully suggests the need to re-examine certain 
considerations about the geomorphological processes in the study area. Previous research (BENAC et al., 2005; JURAK et al., 2005; ALJINOVIĆ et al., 2010) suggests that excessive erosion predominates in the development of the Slani Potok gully, with the landslides formed in the eroded soil mass as the associated phenomena. Thereby, the landslides were never investigated in detail, given the available conventional research methods involving only field investigations, which did nor enable the identification of individual landslides and the production of an appropriate landslide inventory of the Slani Potok gully. Only the recent and new technologies for landslide mapping, such as the LiDAR technology, have enabled the detailed topographic analysis and recognition of such a large number of individual landslides. Considering the main findings of this study, it can be concluded that the initiation of a large number of landslides along the gully channel margins predominantly affects the morphologic development of the Slani Potok gully, and that soil erosion is the secondary process, which has a greater affect on the soil mass displaced by landslides than the flysch bedrock. Erosion processes are nevertheless significant, as they are considered to be one of the main landslide preparatory causal factors in this area.

Finally, it is considered that the presented historical landslide inventory map of the Slani Potok gully can significantly contribute to the sustainable land development in the study area, and that it can be efficiently used for future landslide susceptibility analysis. The information about landslide types and their additional characteristics can also contribute to geomorphological analyses in predicting the future development of the Slani Potok gully, as well as the general landscape evolution in the central part of the Vinodol Valley.

\section{ACKNOWLEDGMENT}

The results presented herein have been obtained in the framework of the Croatian-Japanese bilateral project Risk Identification and Land-Use Planning for Disaster Mitigation of Landslides and Floods in Croatia, funded by the Japan Agency for Science and Technology (JST) and Japan International Cooperation Agency (JICA) through the Science and Technology Research Partnership for Sustainable Development (SATREPS) Program.

\section{REFERENCES}

ALJINOVIĆ, D., JURAK, V., MILEUSNIĆ, M., SLOVENEC, Dr. \& PRESEČKI, F. (2010): The origin and composition of flysch deposits as an attribute to the excessive erosion of the Slani Potok Valley ("Salty Creek"), Croatia.- Geologia Croatica, 63/3, 313-322. doi: 104154/gc.2010.25

AMUNDSEN, J., JOHNSON, S., ROUSE, K. \& WANG, H. (2010): Using LiDAR-derived DEMs to delineate and characterize landslides in Northern Kentucky and Hamilton County, Ohio. Retrieved from http: //www.trishock.com/academic/pdf/ lidar_landslides.pdf

ANTONINI, G., ARDIZZONE F., CARDINALI, M., GALLI, M., GUZZETTI, F. \& REICHENBACH, P. (2002): Surface deposits and landslide inventory map of the area affected by the 1997 Umbria-Marche earthquakes.- Bollettino della Societa Geologica Italiana, 121/2, 843-853.

ARBANAS, Ž. (2000): Geotehnički projekt županijske ceste ŽC 5064 Križišće - Tribalj - Grižane - Bribir - Novi Vinodolski, dionica Barci (Grižane) [Geotechnical design of the county road CR 5064 Križišće - Tribalj - Grižane - Bribir - Novi Vinodolski, route Barci (Grižane) - in Croatian].- Institut građevinarstva Hrvatske, PC Rijeka.

ARBANAS, Ž. (2002): Klizište Ugrini na županijskoj cesti ŽC 5062 Bribir - Lič, Idejni projekt sanacije [Ugrini landslide on county road CR 5062 Bribir - Lič, Preliminary design - in Croatian].- Institut građevinarstva Hrvatske, PC Rijeka.

ARDIZZONE, F., CARDINALI M., GALLI M., GUZZETTI, F. \& REICHENBACH, P. (2007): Identification and mapping of recent rainfall-induced landslides using elevation data collected by airborne LiDAR.- Natural Hazards and Earth System Sciences, 7, 637-650. doi: 10.5194/nhess-7-637-2007

BELL, R., PETSCHKO, H., RÖHRS, M. \& DIX, A. (2012): Assessment of landslide age, landslide persistence and human impact using airborne laser scanning digital terrain models.- Geografiska Annaler: Series A, Physical Geography, 94, 135-156. doi: 10.1111/j.1468-0459.2012.00454.x

BERNAT, S., ĐOMLIJA, P. \& MIHALIĆ ARBANAS, S. (2014): Slope movements and erosion phenomena in the Dubračina River Basin: a geomorphological approach.In: MIHALIĆ ARBANAS, S. \& ARBANAS, Ž. (eds.): Proceedings of the $1^{\text {st }}$ Regional Symposium on Landslides in the Adriatic-Balkan Region: Landslide and Flood Hazard Assessment. Zagreb: Croatian Landslide Group - Faculty of Mining, Geology and Petroleum Engineering of the University of Zagreb and Faculty of Civil Engineering of the University of Rijeka, 79-84.

BERNAT GAZIBARA, S., KRKAČ, M. \& MIHALIĆ ARBANAS, S. (2019): Verification of historical landslide inventory maps for the Podsljeme area in the City of Zagreb using LiDAR-based landslide inventory.- The Mining-Geology-Petroleum Bulletin, 34/1, 45-58. doi: 10.17794/rgn.2019.1.5

BENAC, Č., JURAK, V., OŠTRIĆ, M., HOLJEVIĆ, D. \& PETROVIĆ, G. (2005): Pojava prekomjerne erozije u području Slanog potoka (Vinodolska dolina) [An excessive erosion phenomenon in the Slani Potok (Vinodol Valley) - in Croatian]. - In: VELIĆ, I., VLAHOVIĆ, I. \& BIONDIĆ, R. (eds.): Abstracts Book of the $3^{\text {rd }}$ Croatian Geological Congress, Croatian Geological Survey, Zagreb, 173-174.

BIONDIĆ, B. \& VULIĆ, Ž. (1970): Klizište Grižane 1968. Inženjerskogeološki radovi [Grižane Landslide 1968 - Engineering geological investigations - in Croatian].Institut za geološka istraživanja, Zagreb.

BLAŠKOVIĆ, I. (1999): Tectonics of Part of the Vinodol Valley Within the Model of the Continental Crust Subduction.- Geologia Croatica, 52/2, 153-189. doi: 10.4154/GC.1993.13

CEAN, CROATIAN AGENCY FOR ENVIRONMENT AND NATURE (2008): Corine Land Cover Croatia, Land Use Map 1:100,000.

CLAGUE, J.J. \& ROBERTS, N.J. (2012): Landslide hazard and risk.-- In: CLAGUE, J.J. \& STEAD, D. (eds.): Landslides: Types, Mechanisms and Modeling.-Cambridge, University Press, United Kingdom, 1-9. doi: 10.1017/CBO9780511740367.002

CROZIER, M.J. (1986): Landslides: Causes, Consequences and Environment.- Croom Helm, England.

CROZIER, M.J. (2010): Landslide geomorphology: An argument for recognition, with examples from New Zealand.- Geomorphology, 120/1-2, 3-15. doi:10.1016/j. geomorph.2009.09.010

CRUDEN, D.M. \& VARNES, D.J. (1996): Landslide types and processes.- In: TURNER, A.K. \& SCHUSTER, R.L. (eds.): Landslides, Investigation and Mitigation. Transportation Research Board, Special Report 247, Washington D.C., USA, 36-75.

DOMJAN, E. (1965): Izvještaj o terenskim sondažno istražnim radovima na lokaciji klizišta kraj Grižana [Technical report on field investigations of Grižane landslide - in Croatian].- Rijekaprojekt, Rijeka.

ĐOMLIJA, P., BERNAT, S., MIHALIĆ ARBANAS, S. \& BENAC, Č. (2014): Landslide inventory in the area of Dubračina River Basin (Croatia).- In: SASSA, K., CANUTI, P. \& YIN, Y. (eds.): Landslide Science for a Safer Geoenvironment, Vol. 2. Methods of Landslide Studies, Springer International Publishing, 837-842. doi: 10.1007/978-3-319-05050-8_129

ĐOMLIJA, P. (2018): Identification and classification of landslides and erosion phenomena using the visual interpretation of the Vinodol Valley Digital Elevation Model.- Dissertation. University of Zagreb, Faculty of Mining, Geology and Petroleum Engineering.

ĐOMLIJA, P., BERNAT GAZIBARA, S., ARBANAS, Ž. \& MIHALIĆ ARBANAS, S. (2019a): Identification and mapping of soil erosion processes using the visual interpretation of LiDAR imagery.- ISPRS International Journal of Geo-Information, 8, 438. doi: 10.3390/ijgi8100438

ĐOMLIJA, P., PRŠA, M., JAGODNIK, V. \& ARBANAS, Ž. (2019b): Preliminary testing of clay activity from landslide deposits in Dubračina River Basin, Croatia.In: ULJAREVIĆ, M., ZEKAN, S., SALKOVIĆ, S. \& IBRAHIMOVIĆ, Dž. (eds.): Proceedings of the $4^{\text {th }}$ Regional Symposium on Landslides in the Adriatic - Balkan Region. Sarajevo: Geotechnical Society of Bosnia and Herzegovina, 121-126. doi: 10.35123/ReSyLAB_2019_20

FREVERT, R.K. (1955): Soil and water conservation engineering.- Wiley, New York.

GALLI, M., ARDIZZONE, F., CARDINALI, M., GUZZETTI, F. \& REICHENBACH, P. (2008): Comparing landslide inventory maps.- Geomorphology, 94, 268-289. doi: 10.1016/j.geomorph.2006.09.023

GROŠIĆ, M. (2013): Lokalna cesta LC 58075, lokalitet Podbadanj. Geotehnički izvještaj [Local road LR 58075, Podbadanj location. Geotechnical report - in Croatian].Geotech d.o.o., Rijeka.

GUZZETTI, F., MALAMUD, B.D, TURCOTTE, D.L. \& REICHENBACH, P. (2002): Power-law correlations of landslide areas in central Italy.- Earth and Planetary Science Letters, 195, 169-183. doi: 10.1016/S0012-821X(01)00589-1

GUZZETTI, F. (2006): Landslide hazard and risk assessment.- Dissertation. Mathematisch-Naturwissenschaftlichen Fakultät der Rheinischen Friedrich-Wilhelms-Universität, Bonn, Germany.

GUZZETTI, F., MONDINI, A.C., CARDINALI, M., FIORUCCI, F., SANTANGELO, M. \& CHANG, K.T. (2012): Landslide inventory maps: new tools for an old problem.-- Earth-Science Reviews, 112, 42-66. doi: 10.1016/j.earscirev.2012.02.001 
HAUGERUD, R.A., HARDING, D.J., JOHNSON, S.Y., HARLESS, J.L., WEAVER, C.S. \& SHERROD, B.L. (2003): High-resolution LiDAR topography of the Puget Lowland, Washington - a bonanza for earth science. GSA Today, 13/6, 4-10. doi: 10.1130/1052-5173(2003)13<0004:HLTOTP>2.0.CO;2

HUNGR, O., LEROUEIL, S. \& PICARELLI, L. (2014): The Varnes classification of landslide types, an update.- Landslides, 11, 167-194. doi: 10.1007/s10346-0130436-y

ICL, INTERNATIONAL CONSORTIUM ON LANDSLIDES (2018): Instructions for World Reports on Landslides.- Retrieved from https://www.iplhq.org

IGU, INTERNATIONAL GEOGRAPHICAL UNION, COMMISSION ON APPLIED GEOMORPHOLOGY, SUBCOMMISSION ON GEOMORPHOLOGICAL MAPPING (1968). The unified key to the detailed geomorphological map of the World 1: 25,000 - 1: 50000.- In: KLIMASZEWSKI, M. (ed.): Part I. Problems of the detailed geomorphological map; BASHENINA, N.V., GELLERT, J. \& JOLLY, F. et al. (eds.): Part II. Project of the unified key to the detailed geomorphological map of the World. Krakow: Folia Geografica, Series Geographica-Physica 2.

JABOYEDOFF, M., OPPIKOFER, T., ABELLAN, A., DERRON, M., LOYE, A., METZGER, R. \& PEDRAZZINI, A. (2012): Use of LiDAR in landslide investigation: a review. Natural Hazards, 61, 5-28. doi: 10.1007/s11069-010-9634-2

JURAK, V., SLOVENEC, D. \& MILEUSNIĆ, M. (2005): Pretjerana erozija fliša - Slani Potok [An excessive flysch erosion - Slani Potok-in Croatian].- In: BIONDIĆ, R., VLAHOVIĆ, I. \& VELIĆ, I. (eds.): Excursion Guide Book of $3^{\text {rd }}$ Croatian Geological Congress, Croatian Geological Survey, Zagreb, 51-55.

KASAI, M., IKEDA, M., ASAHINA, T. \& FUJISAWA, K. (2009): LiDAR-derived DEM evaluation of deep-seated landslides in a steep and rocky region of Japan.- Geomorphology, 113, 57-69. doi: 10.1016/j.geomorph.2009.06.004

KEATON, J.R. \& DEGRAFF, J.V. (1996): Surface observations and geologic mapping.In: TURNER, A.K. \& SCHUSTER, R.L. (eds.): Landslides, Investigation and Mitigation. Transportation Research Board, Special Report 247, Washington D.C., USA, 178-230.

KOSTENKO, N.P. (1975): Quaternary Deposits of Highlands [in Russian], Moscow.

KOŠIR, A., MARTÍN-PÉREZ, A. \& POPIT, T. (2013): Zakaj je Slano blato slano? [Why is Slano blato salty? - in Slovenian].- In: ROŽÍĆ, B. (ed.): Razprave, poročila = Treatises, reports, $21^{\text {st }}$ Meeting of Slovenian Geologists, Ljubljana, University of Ljubljana, Faculty of Natural Sciences and Engineering, Department of Geology, $75-77$.

MALAMUD, B.D., TURCOTTE, D.L., GUZZETTI, F. \& REICHENBACH, P. (2004): Landslide inventories and their statistical properties.- Earth Surface Processes and Landforms, 29, 687-711. doi: 10.1002/esp.1064

MCCALPIN, J. (1984): Preliminary age classification of landslides for inventory mapping.- Proceedings of the $21^{\text {st }}$ Annual Engineering Geology and Soils Engineering Symposium University Press, Moscow, Idaho, 99-111.

MIHALIĆ, S. \& ARBANAS, Ž. (2013): The Croatian-Japanese joint research project on landslides: activities and public benefits.- In: SASSA, K., ROUHBAN, B., BRICEÑO, S., MCSAVENEY, M. \& HE, B. (eds.): Landslides: Global risk preparedness, Heidelberg: Springer, 333-349.

MIHALIĆ ARBANAS, S. \& ARBANAS, Ž. (2014): Landslides: A guide to researching landslide phenomena and processes.- In: GAURINA MEĐIMUREC, N. (ed.): Handbook of Research on Advancements in Environmental Engineering. Engineering Science Reference, Hershey PA, 474-508. doi: 10.1007/978-3-642-22087-6_24

MIHALIĆ ARBANAS, S., KRKAČ, M. \& BERNAT, S. (2016): Application of advanced technologies in landslide research in the area of the City of Zagreb (Croatia, Europe).- Geologia Croatica, 69/2, 231-243. doi: 10.4154/gc.2016.18

MILEUSNIĆ, M., SLOVENEC, D. \& JURAK, V. (2004): Thenardite-efflorescence indicating cause of the excessive flysch erosion, Slani potok, Croatia.-Acta Mineralogica-petrographica, Abstract Series, 75-75.

MITAS, L. \& MITASOVA, H. (1999): Spatial Interpolation.- In: LONGLEY, P., GOODCHILD, M.F., MAGUIRE, D.J. \& RHIND, D.W. (eds.): Geographical Information System: Principles, Techniques, Management and Applications ( $2^{\text {nd }}$ edition). Wiley, Chichester, 481-492.

MOORE, I.D., GRAYSON, R.B. \& LADSON, A.R. (1991): Digital terrain modelling: a review of hydrological, geomorphological, and biological applications.- Hydrological Processes 5, 3-30. doi: 10.1002/hyp.3360050103

PAJALIĆ, S., ĐOMLIJA, P., JAGODNIK, V. \& ARBANAS, Ž. (2017): Diversity of Materials in Landslide Bodies in the Vinodol Valley, Croatia.- In: MIKOŠ, M., VILIMEK, V., YIN, Y. \& SASSA, K. (eds.): Advancing Culture of Living with Landslides, Volume 5, Springer, 507-516. doi: 10.1007/978-3-319-53483-1_60

PETSCHKO, H., BELL, R. \& GLADE, T. (2016): Effectiveness of visually analyzing LiDAR DTM derivatives for earth and debris slide inventory mapping for statistical susceptibility modeling.-Landslides, 13/5, 857-872. doi: 10.1007/s10346-015$0622-1$

POPIT, T. \& VERBOVŠEK, T. (2013): Analysis of surface roughness in the Sveta Magdalena paleo-landslide in the Rebrnice area.- RMZ - Materials and Geoenvironment, 60, 197-204.

POPIT, T., SUPEJ, B., KOKALJ, Ž. \& VERBOVŠEK, T. (2016): Comparison of methods for geomorphometric analysis of surface roughness in the Vipava valley.-Geodetski vestnik, 60/2, 227-240. doi: 10.15292/geodetski-vestnik.2016.02.227-240
POPIT, T. (2017): Origin of planation surfaces in the hinterland of Šumljak sedimentary bodies in Rebrnice (upper Vipava valley, SW Slovenia).- Geologija, 60/2, 297-307. doi: 10.5474/geologija.2017.021

RAZAK, K.A., STRAATSMA, M.W., VAN WESTEN, C.J., MALET, J.P. \& DE JONG, S.M. (2011): Airborne laser scanning of forested landslides characterization: terrain model quality and visualization.- Geomorphology, 126, 186-200. doi: 10.1016/j.geomorph.2010.11.003

RIB, H.T. \& LIANG, T. (1978): Recognition and identification.- In: TURNER, A.K. \& SCHUSTER, R.L. (eds.): Landslides, Investigation and Mitigation. Transportation Research Board, Special Report 247, Washington D.C., USA, 34-80.

SCAIONI, M., LONGONI, L., MELILLO, V. \& PAPINI, M. (2014): Remote Sensing for Landslide Investigations: An Overview of Recent Achievements and Perspectives.- Remote Sensing, 6/10, 9600-9652. doi: 10.3390/rs60x000x

SCHUSTER, R.L. (1996): Socioeconomic Significance of Landslides.- In: TURNER, A.K. \& SCHUSTER, R.L. (eds.): Landslides, Investigation and Mitigation. Transportation Research Board, Special Report 247, Washington D.C., USA, 12-35.

SCHUSTER, R.L. \& KOCKELMAN, W.J. (1996): Principles of Landslide Hazard Reduction.- In: TURNER, A.K. \& SCHUSTER, R.L. (eds.): Landslides, Investigation and Mitigation.

SOETERS, R. \& VAN WESTEN, C.J. (1996): Slope instability recognition, analysis and zonation.- In: TURNER, A.K. \& SCHUSTER, R.L. (eds.): Landslides, Investigation and Mitigation. Transportation Research Board, Special Report 247, Washington D.C., USA, 129-177.

STRAHLER, A.N. (1952): Hypsometric (area - altitude) analysis of erosional topography.- Bulletin of the Geological Society of America, 63/11, 1117-1142. doi: 10.1130/0016-7606(1952)63\%5B1117:HAAOET\%5D2.0.CO;2

STRAHLER, A.N. (1957): A quantitative analysis of watershed geomorphology.- Transactions of the American Geophysical Union, 38/6, 913-920. doi: 10.1029/ TR038i006p00913

ŠESTANOVIĆ, S. (2001): Osnove geologije i petrografije [Basics of Geology and Petrography - in Croatian].- University of Split, Faculty of Civil Engineering, Split.

ŠTAJDUHAR, M. (1976): Odron na cesti Grižane - Kamenjak (kraj Crikvenice) [Fall on Grižane - Kamenjak road (near Crikvenica settlement) - in Croatian].- Geomechanical report, Geotehnika, Institut "Geoexpert", Zagreb.

ŠUŠNJAR, M., BUKOVAC, J., NIKLER, L., CRNOLATAC, I., MILAN, A., ŠIKIĆ, D., GRIMANI, I., VULIĆ, Ž. \& BLAŠKOVIĆ, I. (1970): Osnovna geološka karta SFRJ 1:100,000, List Crikvenica, L33-102 [Basic Geological Map of SFRY 1:100,000, Crikvenica Sheet L33-102 - in Croatian].- Institut za geološka istraživanja, Zagreb, Savezni geološki zavod, Beograd.

TOMIĆ, A., HRVOJIĆ, E., LUŠIČIĆ, I. \& VELNIĆ, M. (1977): Izvještaj o klizištu Slani potok i Male Dubračine - kod Grižana [Technical report on the Slani Potok and Mala Dubračina landslide - in Croatian].- Opće vodoprivredno poduzeće, Rijeka.

TOŠEVSKI, A. (2013): Inventar klizišta u slivu rijeke Dubračine [Landslide inventory in Dubračina River Basin - in Croatian].- Rudarsko-geološko-naftni zbornik, 27/1, $1-16$.

VAN DEN EECKHAUT, M., POESEN, J., VERSTRAETEN, G., VANACKER, V., MOEYERSONS, J., NYSSEN, J. \& VAN BEEK, L.P.H. (2005): The effectiveness of hillshade maps and expert knowledge in mapping old deep - seated landslides.Geomorphology, 67, 351-363. doi: 10.1016/j.geomorph.2004.11.001

VAN DEN EECKHAUT, M., POESEN, J., VERSTRAETEN, G., VANACKER, V., NYSSEN, J., MOEYERSONS, J., VAN BEEK, L.P.H. \& VANDEKERCKHOVE, L. (2007): Use of LIDAR-derived images for mapping old landslides under forest.- Earth Surface Processes and Landforms, 32, 754-769. doi: 10.1002/esp.1417

VARNES, D.J. (1978): Slope movements, type and processes.- In: SCHUSTER, R.L. \& KRIZEK R.J. (eds.): Landslide Analysis and Control, Transportation Research Board, Special Report 176. National Academy of Sciences, Washington, 11-33.

VARNES, D.J. \& IAEG COMMISION ON LANDSLIDES AND OTHER MASSMOVEMENTS (1984): Landslide hazard zonation: a review of principles and practice.- The UNESCO Press, Paris.

WEHR, A. \& LOHR, U. (1999): Airborne laser scanning-an introduction and overview.ISPRS Journal of Photogrammetry and Remote Sensing, 54/2-3, 68-82. doi: 10.1016/S0924-2716(99)00011-8

WIECZOREK, G.F. (1984): Preparing a detailed landslide-inventory map for hazard evaluation and reduction.- Bulletin of the Association of Engineering Geologists, 21/3, 337-342. doi: 10.2113/gseegeosci.xxi.3.337

WP/WLI, INTERNATIONAL GEOTECHNICAL SOCIETY'S UNESCO WORKING PARTY ON WORLD LANDSLIDE INVENTORY (1993): A suggested method for describing the activity of a landslide.- Bull. Intern. Assoc. Eng. Geol., 47, 53-57.

ZANINOVIĆ, K., GAJIĆ-ČAPKA, M., PERČEC TADIĆ, M., VUČETIĆ, M., MILKOVIĆ, J., BAJIĆ, A., CINDRIĆ, K., CVITAN, L., KATUŠIN, Z., KAUČIĆ, D., LIKSO, T., LONČAR, E., LONČAR, Ž., MIHAJLOVIĆ, D., PANDŽIĆ, K., PATARČIĆ, M. \& VUČETIĆ, V. (2008): Klimatski atlas Hrvatske: 1961-1990, 1971-2000 [Climate atlas of Croatia: 1961-1990, 1971-2000 - in Croatian].-Croatian Meteorological and Hydrological Service, Zagreb. 